\title{
Az (im)mobilitás dinamikái vidéki terekben - szakirodalmi kitekintés, empirikus kiegészítésekkel
}

\section{The dynamics of (im)mobility in rural areas - literature review and some empirical comments}

\author{
VÁRADI MONIKA MÁRIA
}

VÁRADI Monika Mária: tudományos főmunkatárs, Közgazdaság- és Regionális Tudományi Kutatóközpont, Regionális Kutatások Intézete; 1097 Budapest, Tóth Kálmán u. 4.; varadi.monika@krtk.mta.hu; https://orcid.org/0000-0003-4848-7113

KULCSSZAVAK: „új mobilitási paradigma”; holisztikus és relacionális megközelítés; vidéki (im)mobilitás; aspiráció és képesség modell; az immobilitás típusai

ABSZTRAKT: A tanulmány a mobilitás, immobilitás nemzetközi szakirodalmáról kíván (egy óhatatlanul szelektív, töredékes) áttekintést nyújtani, annak érdekében, hogy keresse a kapcsolódási pontokat a magyarországi vidéken zajló (im)mobilitási folyamatok értelmezése, valamint az új mobilitási paradigma képviselői és az immobilitás kutatói által kínált fogalmi és szemléleti keret között.

Az új mobilitási paradigma talán legfontosabb vonása a mobilitás holisztikus megértésének igénye, valamint mobilitás és immobilitás relacionális szemlélete, ami átfordítható empirikus kérdésekké és projektekké a vidékkutatásokban. A magyarországi hátrányos helyzetű vidéki terekben is egyszerre vannak jelen a mobilitás különböző formái, s az emberek életében is egymást feltételezi mobilitás és immobilitás, és e sokszínű folyamatok együttesen formálják, alakítják át a vidék arculatát, a lokális társadalmakat.

Az emberek között egyenlőtlenül oszlanak meg mobilitás és immobilitás esélyei és lehetőségei, s ez az egyenlőtlenség szorosan összefügg az (im)mobilitást szabályozó, ellenőrző és korlátozó rezsimek múködésével. Tim Cresswell szerint a mobilitás egyidejűleg foglalja magába a fizikai mozgást, a mozgás reprezentációit és gyakorlatait, amelyek együttesen hozzák létre a mobilitás különböző korokban és terekben uralkodó együttállásait, amelyek maguk után vonják a mobilitás politikáit is, amelyek egyben az immobilitás politikái is.

Részint a mobilitási fordulatra, a mobilitással szembeni elfogultságra adott reakcióként, részint a migrációkutatás régi adósságát törlesztve fordult a kutatói figyelem az immobilitás felé, különös hangsúllyal a vidéki terekre, amelyet a migráció/mobilitás kutatói gyakran az elmaradottsággal, mozdulatlansággal azonosítanak. A tanulmány Jørgen Carling, Hein de Haas és Kerilyn Schewel aspiráció és képesség modellje alapján mutatja be az (önkéntes, kényszerü, elfogadó) immobilitás (ideál)típusait, és Schewel nyomán az immobilitást tápláló, fenntartó tényezőket is.

Az (im)mobilitáshoz kapcsolódó reprezentációk, jelentések, értelmezések különböző perspektívákból igen eltérőek lehetnek, s ezért alapvető kutatói feladat annak feltárása, hogy az (im)mobilitás milyen jelentéseket hordoz az érintettek számára, s ezek miként függenek össze az életkor, társadalmi nem, osztályhelyzet, etnikai, nemzeti, vallási hovatartozás, egészségi állapot mentén tapasztalható egyenlőtlenségekkel.

Monika Mária VÁRADI: senior research fellow, Institute for Regional Studies, Centre for Economic and Regional Studies; Tóth Kálmán u.4., H-1097 Budapest, Hungary; varadi.monika@krtk.mta.hu; https://orcid.org/0000-0003-4848-7113 
KEYWORDS: 'new mobilities paradigm'; holistic and relational approach; rural (im)mobilities; aspiration and ability model; types of immobility

ABSTRACT: The paper aims to provide a selective review of the literature on the 'new mobilities paradigm' and immobility research with a special empirical focus on rural (im)mobilities. It presents empirical evidence on (im)mobilities collected in different parts of Hungary in order to promote new agendas in Hungarian rural research. Although rural areas have often been described as rather immobile: a world of stability and stillness, rootedness, place-attachment, they are in fact shaped by diverse types of mobilities, which continually reconstruct the 'rural'. Both mobility and immobility represent ways of participating in social life, and each individual act of (im)mobility is embedded in and intersects with spatial, geographic, economic, social and cultural structures, processes.

The 'new mobilities paradigm', conceptualised by John Urry, Mimi Sheller, Peter Adey, Tim Cresswell, and Vincent Kauffman, is part of a broader theoretical project, which aims to challenge 'sedentarist' approach and perspectives in social sciences. The novelty of this 'paradigm' is its incentive to understand mobility as a holistic and relational process. From this perspective, mobility and immobility are interconnected, in a constant dialogue with each other: mobility is possible and recognisable because of the simultaneous presence of stability and immobility.

The ability to be mobile or immobile is conceived as a resource whose availability varies by class position, age, gender, ethnicity, nationality, religion, health conditions, and power relations. Hence, it can be a source of spatial, economic, and social inequalities and inclusion/exclusion. The possibility and capability of being spatially and socially mobile or immobile is inextricably linked to the complex and dynamic interplay between structure and agency. The question is how structure and people's aspirations and capabilities mutually constitute one another. Mobility as well as immobility can be voluntary or involuntary, free or forced, people aspire to be (im) mobile or not, and they are capable of being (im)mobile (in terms of having access to financial, cultural and social capitals or not).

The aspiration and ability model, developed by Jørgen Carling, Hein de Haas and Kerilyn Schewel provides a theoretical model to identify types of (voluntary, involuntary and acquiescent) immobilities. In addition, the question of why people aspire to stay can be answered by the introduction of some repelling, retaining factors and internal constraints which inextricably shape people's decisions on leaving or staying.

Irrespective of whether people aspire to leave or to stay, mobility and immobility are attached by instrumental and intrinsic values, by culturally specific thoughts and feelings, which can be empirically identified in order to understand the dynamic and complex phenomena of (im)mobilites.

\section{Bevezetés}

E tanulmány megírására az ösztönzött és kínált lehetőséget, hogy kutatótársaimmal bekapcsolódhattunk a Magyar Tudomány Akadémia Kiválósági Együttműködési Program (MTA KEP) Mobilitási Kutatási Centrum keretében folyó programba. Kvantitatív és kvalitatív módszereket egyaránt alkalmazó vizsgálatunk kérdése, hogy a közfoglalkoztatás miként hat a programban résztvevők (im)mobilitására, mennyire ösztönzi, illetve hátráltatja a kilépést a nem támogatott munkaerőpiacra, mennyire zárja be őket munkaerőpiaci, társadalmi pozíciójukba és településükre. ${ }^{1}$ A félig strukturált interjúkon alapuló kvalitatív kutatás lehetőséget ad arra, hogy a közfoglalkoztatás és az (im)mobilitás összefüggéseit ne a programra 
szorítkozva, hanem az egyéni és családi életutakra és a lokális társadalmak sajátosságaira, a térbeli és társadalmi (im)mobilitások családi és lokális mintázataira is figyelmet fordítva vizsgáljuk.

Kutatásunk tehát alapvetően egy, a munkanélküliség kezelését szolgáló közpolitikai beavatkozás foglalkozási, területi és társadalmi (im)mobilitásra gyakorolt hatásait kívánja feltárni hátrányos helyzetủ vidéki terepeken. E tanulmányban azonban az eredeti kutatási kérdésen és a közpolitikai elemzés keretein túllépve arra keresem a választ, hogy az (im)mobilitás kutatásához kapcsolódó nemzetközi tudományos diskurzusok kínálnak-e, s ha igen, milyen tanulságokat, fogódzókat, értelmezési kereteket egyfelől szűkebb értelemben vett kutatási kérdésünk megválaszolásához, másfelől tágabban, a vidéki terekben zajló (im)mobilitási mintázatok és dinamikák megértéséhez. A kérdés számomra lényegében úgy hangzik, hogy vajon fontos, releváns tudományos feladat-e ma az (im)mobilitás kutatása a vidéki Magyarországon.

Mobilitás és immobilitás egyaránt hangsúlyosan szerepelnek ebben a tanulmányban. Ennek oka kiinduló kutatási kérdésünkhöz kapcsolódik. Széles körü konszenzus övezi ugyanis azt az állítást, hogy a közfoglalkoztatás erősíti az érintettek immobilitását, amennyiben gátolja a kitörést egy munkaerőpiaci, települési és társadalmi csapdahelyzetből. Ezen túlmenően általános tapasztalat és mérvadó tudományos belátás, hogy mobilitás és immobilitás életünk alapvető, egymást kölcsönösen feltételező tényezői. Ha tehát mozgásról, mobilitásról, migrációról gondolkodunk, nem feledkezhetünk meg a mozdulatlanságról, nyugalomról, helyben maradásról sem. A mobilitás és immobilitás iránti vágy forrása, a döntések oka egyfelől instrumentális, vagyis az emberek megélhetést, boldogulást, biztonságot remélnek attól, hogy elmennek vagy maradnak. Másfelől elmenni vagy helyben maradni önmagában is értéket hordozhat, a szabadságot, önkiteljesítést vagy a közösségi elvárásoknak való megfelelést jelentheti (Carling 2005; de Haas 2014; Carling, Schewel 2018; Schewel 2019). A mobilitáshoz és immobilitáshoz a személyes és családi vágyakban, döntésekben, a lokális és nemzeti diskurzusokban történelmileg és kulturálisan beágyazott értékek, normák, erkölcsi elvárások és ítéletek tapadnak. Kutatási feladat ezek megértése, elemzése is, attól azonban ajánlatos óvakodni, hogy kutatóként jónak vagy rossznak minősítsük akár a migráció, akár a helyben maradás gyakorlatait, s arra kell törekednünk, hogy megértsük az (im)mobilitás dinamikáit kiváltó strukturális okokat, valamint azt, ahogy az emberek a mindenkori korlátok és lehetőségek között megélik, értelmezik vágyaikat, döntéseiket.

Tanulmányom nem empirikus kutatási eredmények szisztematikus elemzését tartalmazza, hanem egy óhatatlanul szelektív és szubjektív nemzetközi szakirodalmi áttekintésen alapul, amellyel párbeszédbe kívánja hozni a magunk és más hazai kutatások tapasztalatait. Saját kutatási eredményeinkre tehát csupán példaként hivatkozom ott, ahol ezt indokoltnak tartom. 


\section{Kiindulópont: új mobilitási paradigma, mobilitási fordulat}

A társadalomtudományokban az ezredfordulón egy viszonylag gyorsan nagy befolyásra és népszerűségre szert tevő kutatási irányzat (Merriman et al. 2013) indult útnak, amelyet Mimi Sheller és John Urry 2006-ban megjelent tanulmánya nyomán „új mobilitási paradigmának” ('new mobilities paradigm') vagy „mobilitási fordulatnak" ('mobilities turn') neveznek. ${ }^{2}$ Az új mobilitási paradigmát Sheller és Urry egy tágabb elméleti vállalkozás részének tekinti, amely kritikus a „statikus” társadalomtudományokkal szemben, és a mozgásokra fókuszálva meg kívánja haladni a társadalmak „konténerterületének” megrögzült képzeteit, valamint a lokális és a globális, a mikro- és a makroszint közötti léptékbeli különbségeket (Sheller, Urry 2006, 209-210; lásd áttekintően Berger 2018, 167-169.). Az új mobilitási paradigma szerint a társadalomtudományoknak túl kell lépniük a „szedentarizmus szemléletén", amely a helyet, a lokalitáshoz való kötöttséget, a helyben maradást, a rögzült jelentést tekinti normális jelenségnek, míg a változást, a mozgást, a helynélküliséget és a jelentések eltolódását e normalitástól való eltérésként kezeli. ${ }^{3}$ E paradigmaváltást az teszi elkerülhetetlenné, hogy a 21. század globális világát korábban nem látott mértékủ és intenzitású mobilitás jellemzi. ${ }^{4}$ Egyre többen és egyre többféleképpen mobilak, úgy tünik, mintha az egész világ úton lenne: például migránsok, turisták, terroristák, diákok, menedékkérők, az üzlet és a tudomány képviselői, dolgozók, katonák, családtagok, NGO-k tagjai (Hannam, Sheller, Urry 2006; Sheller, Urry 2006).

Az „új mobilitási paradigma”, ${ }^{5}$ hangsúlyozza áttekintő írásában Tim Cresswell (2010b), nem a semmiből keletkezett. Legközvetlenebb elődjének a szállítás, közlekedés geográfiája tekinthető, amely azonban hagyományosan a pozitivista tértudományokhoz kötődik. A „mobilitási fordulatnak” ágyaztak meg viszont az olyan, különböző diszciplínákhoz tartozó elméleti munkák szerzői, ${ }^{6}$ akik a mobilitást a modern és posztmodern világ alapvető tényének tekintik és megkérdőjelezik azon szemlélet elsőbbségét, amely szerint a hely (place) mint identitásképző erő a kötöttséggel, meggyökeresedettséggel azonos. Ehhez az elméleti irányhoz kapcsolódott a szociológus Vincent Kaufmann és John Urry (utóbbihoz lásd Berger 2018,167-169.), akik szerint az általunk ismert társadalmak mobilitás (utazás, turizmus, szállítás, kommunikáció) nélkül egyszerűen nem működnének, ezért van szükség arra, hogy a társadalom koncepcióját egy, a mozgásra támaszkodó megközelítésre cseréljük fel (lásd Adey 2017 [2010], 9.). „Mindezek a munkák alapvető ontológiai és episztemológiai kérdéseket tesznek fel, arra ösztönözve bennünket, hogy ne olyan nézőpontból induljunk ki, amelyek magától értetődően adottnak tekintik a kötöttséget (boundedness) és az állandóságot (fixity), inkább induljunk ki a mobilitásból, amely az élet alapvető geográfiai ténye" (Cresswell 2010b , 551.). ${ }^{7}$ Mobilitás nélkül nem tudnánk eljutni a munkahelyünkre vagy beszerezni az ételeinket, nem tudnánk kialakítani, fenntartani családi, baráti kapcsolatainkat, nem tudnánk utazni (az utazásról mint a mobilitás alapvető me- 
taforájáról és jelentőségéről lásd Urry 2002; Salazar 2017), ahogy menekülni sem tudnánk háborúk, az etnikai, faji vagy vallási üldöztetés veszélye elől; mindennapi rutinjaink is a mobilitás megtestesülései (Adey 2017 [2010], 2.).

\section{Mobilitás és immobilitás viszonyrendszerei}

Ami a mobilitásokra fókuszáló megközelítést megkülönbözteti a mozgásról, migrációról, közlekedésről és szállításról készült, egymástól elkülönült diszciplínákhoz köthető munkák sorától, ${ }^{8}$ az a mobilitás holisztikus megértésének igénye. Ez a megközelítés képes összekapcsolni a mozgás legkülönbözőbb fajtáit a mikromozgásoktól (mint a tánc, a séta, a hegymászás, autóvezetés, repülés, vagy akár csak egy mozdulat), a közlekedésen át az áruk, a pénz, a munka legális vagy illegális globális áramlásáig, a nemzetközi migrációig, vagyis az emberi test (testrészek) léptékétől a globális léptékig. Az új mobilitási paradigma képviselői szerint a mobilitás nem csupán a kutatás tárgya, hanem értelmezési keret (Rosenberg, Shannon 2018), az elemzés sajátos perspektívája, analitikus eszköz (Salazar 2017). ${ }^{9}$

Peter Adey a mobilitást „megélt viszonynak” tekinti, a mobilitás „az ember orientációja önmaga, mások és a világ felé (...) az emberek, tárgyak, dolgok és helyek felé fordulás módja. A jelentések és jelentőségek kommunikációjának és egyúttal az autoritárius rezsimekkel szembeni ellenállás módja is (...), mindig valakivel vagy valamivel szemben való viszonyban születik"(Adey 2017 [2010], xv.). A mobilitás olyan viszony, amelyen keresztül az ember megéli és megérti a világot (lásd még Salazar 2017).

Az új mobilitási paradigma a mobilitásról tehát alapvetően viszonyrendszerekben gondolkodik, arra kérdez rá, hogy a mobilitás, a mozgás milyen relációban áll a különböző helyekkel, a megállással (stopping), a helyben maradással, nyugalommal (stillness) és az immobilitással, amelyek egyfelől maguk is függenek a mobilitástól, másfelől lehetővé teszik azt. A paradigma a mozgás és az állandóság, kötöttség, a mozgás és a helyek, a mobilitás és immobilitás relacionális megértésére törekszik, a "mobil és állandó elemek változó együttállásaira és alakzataira" helyezi a hangsúlyt, így lényegében a „mobilitás és immobilitás, a fluiditás és stabilitás" paradigmája (Canzler, Kaufmann, Kesselring 2008, 2.). A mobilitás különböző formái nem érthetőek meg és nem írhatók le a térbeli, infrastrukturális, intézményes csomópontok (nodes) vagy „kikötők” ('moorings') nélkül, amelyek alakítják, terelik, s egyúttal lehetővé is teszik a mobilitásokat. A repülőterek, autópályák, vasútvonalak, állomások, benzinkutak, pihenőhelyek, szállások stb., valamint a kommunikáció globális infrastruktúráját David Harvey nyomán „stabil térbeli pontoknak" ('spatial fixs') is nevezik (Canzler, Kaufmann, Kesselring 2008; Hannam, Sheller, Urry 2006).

Peter Adey a repülőtér példáján érvel a mobilitás és immobilitás relacionális szemlélete mellett. Számára a mobilitás, amely keletkezést (becoming) és folyamatot (process) jelent, a világ ontológiai abszolútuma. A mobilitás és a stabilitás, a 
szedentarizmus és a „nomád metafizika”11 szembeállítását meghaladva a helyek és az immobilitás relatív természetére hívja fel a figyelmet. A müködtetés, fenntartás és felújítás gyakorlatai, a repülőtéren áthaladó emberek áramlásai, az ott dolgozók napi rutinjai révén a mobilitások teremtik meg és újra ezt a teret, amely ebből következően egyáltalán nem tekinthető az állandóság, stabilitás, változatlanság helyének. Ahogy a helyekre mint viszonylagosan rögzített pontokra, mozgásokra és áramlásokra kell tekintenünk, úgy a mobilitásról is érdemes úgy gondolkodnunk, hogy soha nincs abszolút immobilitás, azt, amit, tévesen, akként értelmezünk, relatív immobilitásnak nevezhetjük. Másként fogalmazva, ha minden mobil - s ez Adey ontológiai kiindulópontja -, akkor az immobilitás, illetve a csomópontok, „kikötők" (mint a repülőterek) is mobilak. Vagyis a viszonyrendszerek eredendően magukba foglalják a mobilitást (Adey 2006).

\section{A holisztikus és relacionális megközelítés lehetséges értelmezései a vidéki (im)mobilitás kutatásában}

A holisztikus és relacionális megértés igénye kutatási feladatként azt jelenti, hogy a különböző térbeli léptékű egyéni, családi/háztartási, közösségi szintű (im)mobilitásokat, mozgást és helyben maradást egymáshoz való dinamikus viszonyukban, kölcsönös összefüggésükben vizsgáljuk.

Ez a megközelítés magába foglalhatja az egyéni és csoportos (im)mobilitási utak és mintázatok mindennapi ritmusának, irányainak, dinamikáinak jelen idejü, aktuális követését. Az iskolába, munkába járás gyakorlatai, a munkavégzés, bevásárlás rutinjai, a településen belüli vagy onnan kifelé, városok, központok felé irányuló közlekedés iránya, hatóköre, gyakorisága, tartóssága a mobilitás/immobilitás markánsan azonosítható lokális mintázatait rajzolják ki, amelyek a társadalmi mobilitással is összefüggést mutat(hat)nak, és önmagukban is fölvázolják egy-egy helyi társadalom demográfiai, gazdasági, társadalmi szerkezetét, földrajzi, közlekedési elhelyezkedésének következményeit. Az (im)mobilitás mindennapi, rendszeres rutinjainak feltárása kutatási feladatként „mobil kutatási módszertan” 12 kidolgozását és alkalmazását is igényelheti. Minimális programként pedig egyegy település bejárásai során a térszerkezet, az épületek funkciójának, állapotának, állagának az itt élők tipikus mozgásainak, e mozgások jellegzetességeinek rögzítését (terepnaplóban, térképeken).

A mindennapi egyéni, csoportos (im)mobilitások utalhatnak az adott lokalitás, vidéki tér egészét jellemző és átalakító mozgások dinamikájára, a települési szintü ki- és beáramlások múltbeli és jelenkori sajátosságaira (lásd például Németh 2016). A vidéket gyakran ma is a passzivitással és állandóssággal azonosítjuk, olyan térként, amelyet csak a város, a városi élet felől érnek változást hozó hatások; az ingázással, az új emberek, családok beköltözésével, az elköltözöttek hazalátogatásával, a hétvégi turisták megjelenésével (Bell, Osti 2010). Ténylegesen a 
mai Európa vidéki, periferikus tájain többféle mobilitási folyamatot azonosíthatunk és az érkezők sokszínűségét láthatjuk, sokan, sokfelől és sokféle okkal és céllal érkeznek vidéki terekbe; vannak, akiket az ellenurbanizáció hajt, mások munkavállalás vagy életformaváltás céljából érkeznek, ahogy vannak, akik menedékkérőként jelennek meg (Kordel, Weidinger 2018). A periferikus vidéki terekbe irányuló migráció folyamatosan rekonstruálja a vidéki helyeket. Mindebből következően a "vidék" nem tekinthető mozdulatlannak, állandónak, hanem olyan változások, átalakulások színtere, amelyeket a globalizáció és a mobilitás tágabb folyamatai és a migráció sokszínűsége felől érthetünk meg (Kordel, Weidinger 2018, xv.; a magyar mobilitási mintázatokhoz lásd például Fejős, Szijártó 2002; Csurgó 2007, 2013; Horzsa 2018; Kovách 2012; Vigvári 2016).

Michael Bell és Giorgio Osti a mobilitás és a stabilitás/helyben maradás egymáshoz való viszonya alapján négyféle logikai és egyben praktikus kombinációt különböztet meg, amelyek eltérő módon érintik a vidéki emberek életét és a vidéki tereket. (1) A megfordíthatóság logikája ('reversibility') azt jelenti, hogy a vidék az alapvető, a legfontosabb hely, ahol az ember él, ahonnan rendszeresen vagy időszakosan eljár, legyen ingázó vagy külföldről visszatérő, cirkuláló migráns. A mobilitás ilyen esetekben nem jár visszafordíthatatlan következményekkel, nem vezet elnéptelenedéshez. (2) A megsokszorozás ('recursiveness') logikája szerint a vidék az ember életének mások mellett csak az egyik színtere. Példaként említhetjük azokat, akik a több helyen (városban, vidéken) élnek, esetleg transznacionális migránsként két vagy több országhoz és helyhez is kötődnek. Az ilyen esetekben a mobilitás köti össze a különböző vidéki és urbánus helyeket. (3) Az elkalandozás ('discursiveness') logikája a centrumokból a szimbolikusan értékesnek tekintett vidék felé induló időszakos mobilitásé; a szerzők példaként nem csak a turizmust, de a kutatói terepmunkát is említik. (4) Végül a visszafordíthatatlanság ('irreversibility') logikája azt a folyamatot jelöli, amelynek eredményeként a vidék elhagyott térré válik, ahová már nem lehet/érdemes visszatérni; a modernizáció, urbanizáció és a végleges migráció járhat ezzel a kiürüléssel (Bell, Osti 2010, 202-203.).

Bell és Osti tipológiájában nem jelenik meg a mobilitás és immobilitás viszonyának azon logikája és gyakorlata, amelyek a végletesen szelektív mobilitás (elvándorlás) mellett a helyben maradók etnikai, társadalmi és térbeli szegregációjához, településen belüli, települési vagy térségi szintü kirekesztettséghez vezetnek. A bezáruló immobilitás logikájaként azonosítható folyamatot jól dokumentálják a Magyarország periferikus és aprófalvas vidéki térségeiben lezajlott empirikus kutatások (lásd például Feischmidt 2008; Kovács 2008; Durst 2008; Virág 2007, 2010; Virág, Váradi 2017).

Egy-egy vidéki térségben és településen belül is egymás mellett létezhetnek az (im)mobilitás különböző mintázatai: fiatalok elvándorlása, hosszabb-rövidebb ideig tartó külföldi munkavállalás, transznacionális migráció, ingázás, városiak vagy külföldiek megjelenése, a jóléti migráció, a hajdani lakosok visszaköltözése, 
kényszerű vagy magától értetődő helyben maradás. E különféle (im)mobilitások együtt alakítják át a vidéki lokalitásokat, és teremtenek újfajta mobilitásokat is: gondoljunk például a kutyasétáltató külföldi nyugdijasok látványára eldugott aprófalvakban, azokra az alkalmi munkalehetőségekre, amelyeket az új betelepülők a helyieknek kínálnak, vagy a kommunikáció új módjaira a transznacionális családok külföldön és itthon élő tagjai között.

Mobilitás és immobilitás relacionális szemlélete azt feltételezi, hogy mobilitás és immobilitás egymás nélkül elképzelhetetlenek. A migrációkutatások alapvető tapasztalata, hogy a nemzetállami határokon átnyúló transznacionális viszonyrendszerek részei az otthon maradó családtagok is, a migráció és helyben maradás feltételezik egymást, a migráció célja az otthon maradók támogatása, miközben a migrációhoz az otthon maradó családtagok támogatása is szükséges (a teljesség igénye nélkül Faist 2010, 2016; Szelényi 2016; Mata-Codesal 2015). Peter Adey nyomán állíthatjuk, hogy az immobilitás viszonylagos, s hogy a mobilitás és immobilitás kölcsönhatásának dinamikája egy-egy ember, család életében is változhat a külső strukturális (gazdasági, társadalmi) feltételek, illetve az élethelyzetek, családi ciklusok (családalapítás, gyermekvállalás, nyugdíjazás, betegségek stb.) változásának függvényében.

A strukturális viszonyokat, megélhetési feltételeket és perspektívákat radikálisan átalakító változások, mint a rendszerváltás, az uniós csatlakozás, az uniós munkaerőpiac megnyílása, a 2008-as válság, vagy napjainkban a koronavírus-járvány alapvetően átalakíthatják mobilitás és immobilitás viszonyait, s tehetnek tömegesen immobillá vagy mobillá embereket, társadalmi csoportokat (lásd Czibere, Kovách 2019; Váradi et al. 2017). A strukturális változások akár a legszegényebb, korábban kimozdíthatatlanul immobilnak tekintett roma családokat is mobillá tehetnek, s az (im)mobilitás változatos folyamatait indíthatják el. Ezek a családok elindulhatnak külföldre, ahol végleg letelepedhetnek, vagy mozognak az országok között, esetleg visszatorlódnak lakóhelyükre és hosszabb-rövidebb időre megint immobillá válnak (Durst 2018 a,b, 2019; Vidra 2013a). A térségi munkaerőpiac keresletének bővülése, például egy betanított munkásokat foglalkoztató multinacionális összeszerelő üzem megjelenése nagy számban beterelhet a munkaerőpiacra korábban a gazdaság formális szegmenségben elhelyezkedni nem vagy csak nehézségek árán képes roma embereket (Vidra 2013b). Legújabb kutatási eredmények és saját tapasztalataink is azt mutatják, hogy a válság lecsengése után fellépő munkaerőhiány eredményeként a közfoglalkoztatásból jelentős mértékủ kiáramlás zajlott le (lásd erről részletesen Koltai 2018), s ennek köszönhetően olyan sérülékeny csoportok, emberek is mobillá váltak a munkaerőpiacon, s mozdultak ki lakhelyükről, akiknek korábban esélyük sem volt kikerülni a munkaerőpiaci, területi és társadalmi kirekesztés csapdájából (lásd Kovai, Vigvári 2020). (2020 tavaszán pedig a koronavírus-járvány következtében egy újabb visszarendeződés szemtanúi lehettünk.)

Mobilitás és immobilitás egyidejüsége jellemezheti az ember életének egy-egy szakaszát is. Egyik terepünkön, egy dél-dunántúli városban a szocializmus évei 
alatt a felszámolt cigánytelepekről városi szociális bérlakásokba költöztették a családokat. Míg a roma férfiak esetében a lakás- és a munkaerőpiaci mobilitás - a város bányájában és iparában bőségesen rendelkezésre álló munkahelyeknek köszönhetően - együtt járt, addig az asszonyok számára az életkörülményeik jelentős javulását eredményező lakásmobilitás, költözésük a szegregált telepről a városba nem hozta magával munkaerőpiaci mobilitásukat, ők nem léptek ki a bányászfeleség és családanya hagyományos szerepéből.

Mobilitás és immobilitás különböző léptékeinek kölcsönhatását, idővel bekövetkező változásait pedig egy dél-dunántúli faluban élő, középkorú közfoglalkoztatott férfiak példája illusztrálhatja. Ezek a férfiak hosszú éveken át az állami erdészet alkalmazottai voltak, az erdőn, szabad levegőn dolgoztak, nehéz fizikai munkát végeztek. Ők nem csak életkoruk miatt nem akarnak és képesek elmenni a faluból és szalagmunkát végezni, hanem mert a szabad levegő után irtóznak a bezártságtól, és mert a kezük nem áll rá finommozgást igénylő tevékenységre. Ebben az esetben a mobilitás egyik alapformáját jelentő munkavégzéshez kapcsolódó mindennapi, testbe íródott rutinok, készségek is akadályozzák a munkaerőpiaci mobilitást, s zárják be e férfiakat a támogatott munkaerőpiacra. Ugyanakkor a közfoglalkoztatás mellett a falu és a környék viszonylag sok idényjellegü és napszámos (szabadban végezhető) munkalehetőséget kínál mezőgazdasági vállalkozók gazdaságaiban vagy helyi idősek kertjeiben, így az informális munkavégzéshez kapcsolódó mobilitás és a közfoglalkoztatáshoz kötődő immobilitás egyszerre biztosítja megélhetésüket és strukturálja mindennapjaikat.

\section{Mobilitás, motilitás és egyenlőtlenségek}

A mobilitás, legáltalánosabb definíciója szerint, emberek, dolgok mozgása a reális vagy virtuális világban (Kaufmann 2002, idézi Canzler, Kaufmann, Kesselring 2008, 2.). A mobilitás ugyanakkor nem kizárólag magukból a mozgásokból áll, hanem az ezekhez kötődő emberi szándékok, stratégiák, választások által meghatározott képességek, valamint a lehetőségek rendszeréből is. Mivel a mobilitás nem csupán földrajzi, hanem alapvetően társadalmi térben zajlik, Canzler, Kaufmann és Kesselring a mobilitást a körülmények, feltételek (conditions) változásaként ${ }^{13}$ definiálják, a mozgások, a hálózatok és a motilitás/mozgékonyság (motility) dimenzióira koncentrálva. A mozgás ${ }^{14}$ kizárólag a földrajzi dimenzióra, a helyek közötti mozgásokra vonatkozik, a hálózatok pedig egyaránt lehetnek technikaiak (közlekedés, szállítás, telekommunikáció infrastruktúrái) és társadalmiak, vagyis különböző emberek, csoportok tagjai között létesülnek és lehetővé teszik, elősegítik a mobilitást. A motilitás (mozgékonyság) pedig az emberek térbeliés társadalmi mobilitásra való képességét jelenti; a hálózatokhoz való hozzáférés képességét, az ahhoz szükséges tudást és készségeket, hogy a technikai és társadalmi hálózatokon keresztül kínálkozó lehetőségeket megragadják, valamint azt a módot is, 
ahogy az emberek ezeket a hálózatokat, tudást, készségeket alkalmazzák, felhasználják (lásd még Cresswell 2010a). ${ }^{15}$

A mozgás változatos, sokszínű gyakorlatokat jelent, különböző emberek különböző módokon mozognak (Adey 2006, 2017 [2010]). A motilitás, a földrajzi és társadalmi mobilitásra való képesség különbségei nem érthetők meg pusztán a szereplők szándékai felől, mindig kérdés, hogy azok hogyan függenek össze a lehetőségek és kényszerek rendszereivel. Peter Adey szavaival: „Különböző képességgel rendelkezünk a mobilitásra, s az a mód, ahogy a világ lehetővé teszi vagy korlátozza a mobilitásunkat, perdöntő abban, hogy jó életet élhessünk" (Adey 2017 [2010], 4.). A mobilitás a társadalmi integráció és így a társadalmi különbségek és egyenlőtlenségek forrása és egyben fontos tényezője is. A mobilitáshoz, a mobilitást elősegítő hálózatokhoz, erőforrásokhoz való hozzáférés, a mobilitás lehetősége egyenlőtlenül oszlik meg osztályhelyzet, társadalmi nem, etnicitás, faj, vallás, életforma, egészség/valamilyen fogyatékosság vagy a kibocsátó ország, lakóhely mentén. A mobilitást irányító, terelő csomópontok, mint például a repülőterek is úgy müködnek, hogy ellenőrző rendszerei megszürik az utazókat, elválasztják egymástól a „kinetikus elitet” és azokat, akik nem vagy korlátozottan férnek a mobilitáshoz (mobility poor).

Kaufmann és Widmer (2006) a motilitás szinonimájaként használják a mobilitási tőke fogalmát, amely a kortárs modern társadalmakban a társadalmi integráció lényegi eleme. Hasonlóan gondolkodik John Urry, aki szerint közvetlen kapcsolat létezik a társadalmi tőke és a mobilitás között, ${ }^{16}$ amennyiben a társadalmi tőke éppen a mobilitás mértékétől, kiterjedésétől, módjaitól függ. Ebből következően minden olyan beavatkozás, amely korlátozni kívánja az emberek mobilitását, egyben gyengíti a társadalmi tőkét és a társadalmi kirekesztés új formáit teremti meg. A mobilitás a társadalmi hálózatok fontos kötőanyaga, az emberek utazása pedig különösen fontos a személyes együttlétek, az emberek közötti közvetlen kommunikáció elősegítésében, hiszen ezek teremtik meg a társadalmi bizalom alapját. A mobilitáshoz, a közlekedés, az utazás lehetőségéhez való hozzáférés társadalmunk legfontosabb gyakorlatában való osztozást jelent, és ennek hiányában nem beszélhetünk társadalmi részvételről. Ha a közlekedésben és mobilitásban való részvételből osztályhelyzetük, nemük, etnicitásuk, életkoruk alapján kizárnak embereket, csoportokat, akkor a társadalmi-térbeli kirekesztés sajátos formájáról, a mobilitásból való kirekesztésről (mobility-exclusion) beszélhetünk (Urry 2002, 265.).

Periferikus magyarországi vidéki terekben - csökkenő népességü, elöregedett vagy éppen a gettósodás jeleit mutató kisebb, a fö útvonalakon kívül eső településeken - élők mindennapi tapasztalata, hogy a megfelelő tömegközlekedés (és saját autó) híján nem vagy csak nagy áldozatok árán férnek hozzá munkalehetőségekhez, szolgáltatásokhoz. A mobilitás, a közlekedés, az utazás lehetőségéhez való hozzáférés hiánya vagy korlátozottsága a térbeli, gazdasági, munkaerőpiaci és társadalmi kirekesztettség egyik konstitutív eleme, amely összefüggést mutat 
a vidéki térségeket jellemző (im)mobilitási dinamikákkal. ${ }^{17}$ Üdvözlendő fejleménynek tekinthető, hogy ma már a hazai közlekedésföldrajzi kutatók is foglalkoznak a közlekedési eredetű kirekesztettség problémakörével (Lieszkovszky 2018 a, b).

A mobilitás lehetőségének és esélyének egyenlőtlen elosztása elvezet a hatalom és a mobilitás viszonyrendszerének, kölcsönhatásának problémájához (lásd Adey 2006; Cresswell 2010a, 2012; Sheller, Urry 2006; Merriman et al. 2013; Canzler, Kaufmann, Kesselring 2008). ${ }^{18}$

\section{A mobilitás politikái}

Ebben a fejezetben Tim Cresswell (2010a) inspiráló gondolatmenetét követem, és érvényességét néhány magyarországi kutatási tapasztalattal igyekszem alátámasztani. Cresswell is abból indul ki, hogy a mobilitás nem azonos pusztán a mozgással. A mobilitásban a fizikai mozgás, a mozgás reprezentációi és gyakorlatai kapcsolódnak össze és formálják együttesen a mobilitás különböző korokban és terekben uralkodó együttállásait (constellations), amelyek maguk után vonják a mobilitás sajátos politikáit is. A mobilitás e három eleme természetesen szorosan összefonódik egymással, szétszálazásuk analitikus természetű, de elméleti hozadékkal kecsegtet (Cresswell 2010a, lásd még Cresswell, Uteng 2008).

A fizikai mozgás arra vonatkozik, hogy az egyik helyről eljutunk a másikra (lásd még Hanson 2010); ez a mozgás mérheto", térképre viheto", tervezhető. A fizikai mozgáshoz a legkülönbözőbb társadalmi, kulturális meghatározottságú reprezentációk, jelentések kapcsolódnak; a mobilitást láthatjuk kalandnak, az unalom forrásának, a nevelés/nevelődés eszközének, a szabadság kifejeződésének, modern vagy éppen fenyegető jelenségnek. A mobilitás gyakorlatairól beszélve az olyan mindennapi tevékenységekre gondolunk mint a séta, közlekedés vagy autóvezetés, míg az elméletet tekintve a testté vált (embodied) és bourdieu-i értelemben habitualizált gyakorlatokra. Az emberi mobilitás a testen keresztül valósul meg és a test általi tapasztalat, függetlenül attól, hogy magunk választottuk-e a mobilitást vagy mások kényszerítették ránk. Az emberi mobilitás a test szintjén valósul meg, termelődik újra és alakul át. ${ }^{19} \mathrm{~A}$ mobilitás mint gyakorlat magába foglalja a szándék és a habitus belső, valamint az elvárások/várakozások és kényszerek külső világait (Cresswell 2010a, 19-20.), ${ }^{20}$ ugyanakkor a gyakorlatokhoz különböző diskurzusok is kapcsolódnak, amelyek maguk is hatással lehetnek a gyakorlatokra és azok tapasztalataira (Cresswell 2010a, 22.).

A mobilitás politikája azokra a társadalmi viszonyokra vonatkozik, amelyek magukba foglalják a hatalom termelését és elosztását; a mobilitás e viszonyokat alakítja, ugyanakkor azok eredménye is. A mobilitás politikáját érintő kérdések a fizikai mozgás, a reprezentációk és a gyakorlatok vonatkozásában egyaránt feltehetők. Ki mozoghat egyáltalán, milyen gyakran, milyen gyorsan s milyen messzire juthat el? Az egyes korszakokban milyen narratívák születnek a mobilitásról, miként jelenik meg a mobilitás? (A modernitás narratíváiban például a mobilitás 
gyakran egyenlő a szabadsággal, fejlődéssel.) Hogyan testesül meg a mobilitás? Kényszerű vagy szabad mozgás-e, mennyire kényelmes? Hogy érzi magát az, aki mozog? (Cresswell 2010a, 21.). Mindezek alapján a mobilitás politikája hat elem mentén bontató ki, amelyeket érdemes figyelembe venni, ha a mobilitás egyenlőtlen mintázatait kívánjuk megérteni és elemezni.

(1) Az első kérdés, amit feltehetünk, hogy miért mozog egy ember vagy egy tárgy. Saját döntés vagy strukturális változások eredményeként indul-e valaki útnak, esetleg politikai elnyomás miatt, vagy háború, üldöztetés elől menekül? Nem mindig könnyű elválasztani a mobilitást kiváltó külső kényszereket, belső késztetéseket, ahogy a kényszerü és választott mobilitás között is keskeny lehet a mezsgye.

A külföldi munkavállalásra fókuszáló kutatásunk során azt találtuk, hogy a néhány fiatal kivételével - akik számára a külföldi munka, a hosszabb távollét kalandot, az önállóvá válás útját, vagy gyerekkori álom megvalósítását jelentette -, az embereket a romló megélhetési feltételek, az eladósodottság, a válság következményei, tehát strukturális kényszerek indították útnak. Ugyanakkor az önmegvalósítást, kalandot, tapasztalatot kereső fiatalok migrációs döntéseiben is megjelent a kényszerüség mozzanata, hiszen jellemzően úgy ítélték, hogy önálló életük elindításának feltételei Magyarországon nem adottak (Váradi et al. 2017).

(2) A következő szempont az, hogy egy ember vagy egy tárgy milyen gyorsan mozog. Az emberi mozgás sebessége a mobilitások hierarchiájának alapja, mivel a gyors mozgás, vagyis az, hogy ki milyen gyorsan (ami azt is jelenti, hogy akadályok, ellenőrzés nélkül) jut el az egyik helyről a másikra, egyre inkább az exkluzivitással köthető össze.

A gyorsaság/lassúság dimenziójához kapcsolhatók a munkába járással töltött idő különbségei, ami csak részben függ össze a lakó- és munkahely közötti távolsággal. A betanított munkaerőt foglalkoztató multinacionális cégek munkásbuszai jellemzően faluról falura járva szedik össze a dolgozókat, s ez ugyan zsáktelepüléseken élők számára is megnyitja a tömegközlekedéssel elérhetetlen munkahelyeket, de azzal jár, hogy az utazás rendkívül hosszúra nyúlik és igen megterhelő, s túl hosszú ideig elvonja az ember idejét más, otthon végezhető tevékenységektől, munkalehetőségtől (Vidra 2013b; Váradi 2013; Kovai, Vigvári 2020).

(3) Mindezzel az is összefügg, hogy milyen ritmusban mozog egy ember vagy tárgy. A mozgás és pihenés ismétlődő pillanataiból létrejövő ritmus (legyen szó táncról, költeményről, tornáról vagy munkavégzésről) mindig összekapcsolódik a méréssel, szabályozással, fegyelmezéssel.

Az előzőekben említett példákhoz kapcsolódnék. A hosszú évekig az erdőn dolgozó férfiak brigádjaikban a maguk ritmusa szerint dolgoztak és pihentek, ott az volt a fontos, hogy a napi, heti penzumot elvégezzék, nem ellenőrizték folyton a munkájukat. Ezzel szemben a szalag mellett megkövetelt munka ritmusát, a szünetek hosszát nem a dolgozók szabályozzák, s aki nem tudja fölvenni az ütemet, hozni a normát és türni a monotóniát, kiesik (lásd Vidra 2013b). A munkával és pihenéssel töltött idő ritmusa pedig a jellemzően többműszakos váltásban dol- 
gozó betanított munkások számára akkor is kimerítő és megszokhatatlan lehet, ha három munkanapot három pihenőnap követ (Vidra 2013b; Váradi 2013).

(4) Mivel a mobilitás mindig csatornázott, utak, csomópontok, pihenőhelyek stb. mentén halad, ezért fontos kérdés, hogy milyen útvonalon halad adott ember vagy tárgy. Nem mindegy, hogy milyen közel jön a tömegközlekedés, elérhetők-e a fontos útvonalak, s rajtuk keresztül szolgáltatások stb.

A munkásokat szállító falujáró buszok példáját idézem fel itt ismét, hiszen ebben az esetben az utazás lassúsága a meghosszabbított útvonal eredménye. Aprófalvas vagy tanyás szerkezetü térségekben a fontos útvonalaktól s a központoktól való távolság nagymértékben befolyásolja az (im)mobilitás dinamikáit. A központokba utazás, mindenekelőtt a várakozás (átszállások) idejével egész napot igénylő „kalanddá” tehet egy egyszerű városi ügyintézést is. A távolság a fó útvonalaktól, a tömegközlekedés elégtelen volta és a közlekedéssel járó magas költségek pedig munkaerőpiaci kirekesztettséget és kényszerü immobilitást eredményezhetnek (lásd Váradi 2013).

(5) Alapvető kérdés továbbá, hogy milyen érzést okoz a mobilitás: vajon örömmel, elégedettséggel jár, vagy fájdalmat, kényelmetlenséget, félelmet kelt, s hogy a mobilitás különböző formáihoz milyen reprezentációk, jelentések kapcsolódnak. ${ }^{21}$

A mobilitást kísérő érzések rendkívül különbözőek lehetnek attól függően, hogy ki, honnan, hová, mikor és miért indult útnak, milyen útvonalakhoz, hálózatokhoz fér hozzá, milyen akadályok hátráltatják. Mindennapi és globális léptékű példát említve, a munkába járáshoz kötődő napi bosszúságokat (például a budapesti elővárosi vasútvonalakon), vagy a csatlakozásra várakozás unalmát aligha lehet egybevetni a menekülők kiszolgáltatottságával, átélt félelmeikkel (lásd például Fabio Geda (2012) könyvét egy afganisztáni kiskamasz Olaszországig vezető útjáról).

A mobilitáshoz, azon belül is a munkavégzéshez kapcsolódó jelentésekkel összefüggésben jelenlegi kutatásunkból említek egy jellemző példát. A közfoglalkoztatásban végzett munka ritmusa, intenzitása és a pihenés köré nagyon eltérő (lokális) diskurzusok szerveződnek. Külső szemlélők (vállalkozók, helyi lakosok) gyakran említik az árokparton dohányzó, söprűt támasztó stb., pihenő (lusta) emberek bosszantó látványát - akik láthatóan képtelenek „rendes” munkavégzésre. A közfoglalkoztatást szervezők (polgármesterek, munkavezetők) viszont gyakran azzal magyarázzák engedékenységüket (például elengedik a közfoglalkoztatottakat munkaidőben), mert tudják, hogy máshol is dolgoznak, hogy megéljenek, vagy éppen meg kell otthon etetniük a jószágot. Megint mások úgy érvelnek, hogy a közfoglalkoztatott bérért nem várható el folyamatos, megfeszített munka, belefér a gyakoribb pihenés. A munkavégzést minősíto", a munka hatékonyságához és értékéhez kapcsolódó diskurzusok végső tétje a (munkajogi és társadalmi tekintetben) stigmatizált munkaviszonyban dolgozó közfoglalkoztatottak (lokális) társadalomban elfoglalt pozíciója és önbecsülése. (A közfoglalkoztatás és a „rendes” munka összefüggéseihez lásd Kovai 2019.) 
(6) Végül az a kérdés, mondja Cresswell, hogy mikor és hogyan ér véget a mobilitás, vajon a megállás szándékolt vagy kényszerü? Milyen fizikai és szimbolikus határok állják a mobil emberek és tárgyak útját? Vagyis kik és hogyan szabályozzák az emberek, tárgyak mobilitását? (Cresswell 2010a, 22-27., kiemelések az eredetiben).

A fizikai mozgás, a mozgás reprezentációinak és a mobilitás gyakorlatainak összekapcsolódása történelmileg változó mintázatokat mutat (Cresswell 2010a, 27.), más szóval, a mobilitás jelentéseit a mindenkori társadalmi, kulturális, politikai, történeti beágyazottságai révén nyeri el (Adey 2006, 83.). A mobilitás politikái is beágyazottak az adott történelmi korszakokba, amelyeken azonban átível a mobilitás ellenőrzésére és szabályozására való törekvés; a mobilitás ellenőrzésének szintje az elmúlt ötszáz évre visszatekintve a lokálistól a nemzetállamokon át a globális szintig mozdult el (Cresswell 2010a, 27., a migrációs és mobilitási rezsimekhez lásd még Glick-Schiller, Salazar 2013; Faist 2013).

A mobilitás mindenkori politikája egyúttal az immobilitás politikája is. Az immobilitás viszonylagos (Adey 2006), a tartós helykötödés mellett is mozognak (dolgoznak, vásárolnak, utaznak, sétálnak stb.) az emberek (Schewel 2019, 2.), életüket tehát „kisebb mobilitások” jellemzik (Nagy 2019), és a helyben maradás melletti döntések sem egyszer s mindenkorra szólnak, hanem folyamatos mérlegelés tárgyát képezik (Hjälm 2014, 573.). Az immobilitást is megélt viszonyként, az ember önmaga, mások és a világ felé való fordulásaként (Adey 2017 [2010], habitualizált, kulturálisan és társadalmilag meghatározott gyakorlatként értelmezhetjük, amelyekhez különböző jelentések, reprezentációk kapcsolódnak (Cresswell 2010a, Mata-Codesal 2015, 2018). Az immobilitás lehetőségéhez, esélyéhez való hozzáférés is egyenlőtlenül oszlik el a társadalomban. Ha a gyorsaság privilégium, akkor a lassúság, a lelassulás luxusa sem érhető el mindenki számára (Cresswell 2010a), ahogy arra sincs mindenkinek lehetősége, hogy maga válassza meg a megállás, a nyugalom, az elkülönülés, a visszahúzódás formáit (Adey 2017 [2010], 13.; lásd még Németh 2020). Az immobilitás, akárcsak a mobilitás oka lehet, hogy az ember a helyben maradást részesíti előnyben, de az is, hogy nem képes megvalósítani migrációs törekvéseit (Carling, Schewel 2018, 948.), például azért, mert ebben mobilitási rezsimek megakadályozzák.

\section{Az immobilitásról}

A mobilitási fordulat egyes kritikusai szerint, ha a nomadizmus lencséjén keresztül nézzük és örökös mozgásban lévőnek látjuk a világot, a mozgáshoz pedig csak pozitív értékeket kapcsolunk, akkor nem veszünk tudomást a mobilitás hierarchizált és egyenlőtlen globális mintázatairól. Vagyis a szedentarista szemléletet csupán az ellenkezőjével, a nomadizmussal helyettesítettük (Faist 2013). A szedentarista és nomád paradigma, érvel Kerilyn Schewel, egyaránt a mobilitással szembeni kutatási elfogultságot (mobility bias) erősíti (Schewel 2019). Noha a migrációkutatást már a 
nyolcvanas évektől kísérte a kritika, hogy nem veszi figyelembe az immobilitás okait és következményeit, az évtizedekig háttérbe szorult kutatási témaként (Schewel 2019). A mobilitási fordulatot azután igen hamar követték a kritikai hangok és a várakozásra, nyugalomra, helyben maradásra fókuszáló kutatások (Cresswell 2012).

Az immobilitás kutatói is relacionális szemlélettel fordulnak tárgyuk felé, csak a hangsúly tolódik el és a perspektíva más: a mobilitás, a migráció, mondják, akkor érzékelhető és azért lehetséges egyáltalán, mert egyidejűleg van jelen a stabilitással, a mobilitás hiányával (Mata-Codesal 2015, 2018; Jónsson 2011; Carling, Schewel 2018; Schewel 2019). A kutatói figyelem hiánya mellett a mobilitással szembeni elfogultság azt jelenti, hogy a kutatók a helyben maradásra fóként a migráció perspektívájából tekintenek, s ezért az immobilitáshoz negatív jelentéseket kapcsolnak, fóként, ha vidéki terekről van szó, amelyeket hajlamosak a megrekedtséggel, hátrahagyottsággal azonosítani (Stockdale, Haartsen 2017; Ní Laoire 2001; Jónsson 2011; Schewel 2019). Ebből fakadóan az immobilitást, a helyben maradást a migrációhoz, mobilitáshoz képest reziduálisnak tekintik, és nem veszik figyelembe az immobil emberek ágenciáját, az (im)mobilitás összetettségét, sokszínűségét, változó természetét (Stockdale, Haartsen 2017; Jónsson 2011; Hjälm 2014; Schewel 2019). ${ }^{22}$

Az immobilitás legáltalánosabban azt jelenti, hogy az ember életének a súlypontja egy időszakon keresztül egy adott helyhez kötődik (Schewel 2019). Ez a kötődés egyeseknél élethosszig tarthat, másoknál változhat az élet különböző szakaszaiban, a helyben maradás jelenthet csapdahelyzetet, de lehet vágyott, tudatos életstratégia is (Stockdale, Haartsen 2017; Haartsen, Stockdale 2018; Hjälm 2014; Mata-Codesal 2015, 2018; Carling, Schewel 2018; Schewel 2019, lásd még Csoba 2019; Krémer 2019). A mobilitás iránti elfogultság, a migrációkutatás felé forduló figyelem mellett, szól az érvelés, mintha nem vennénk tudomást arról a tényről, hogy az emberek túlnyomó többsége immobil, nem hagyja el lakóhelyét, nem költözik el sem országon belül máshová, sem külföldre, még akkor sem, ha kedvezőtlen körülmények között él, és ennek tudatában is van (Carling 2002; Carling, Schewel 2018; Fischer et al. 2000; Mata-Codesal 2015; van Houtum, van der Velde 2004; Schewel 2015, 2019; van Naerssen, van der Velde 2015). A kérdés tehát úgy is föltehető, hogy miért nem mozdulnak, miért maradnak az emberek helyben.

\section{Aspiráció és képesség modell}

Az immobilitás (és mobilitás) elméleti igényü elemzési lehetőségét kínálja az aspiráció (aspiration) és képesség (ability) modellje, amely az eredeti, Jørgen Carling nevéhez köthető koncepcióban az immobilitást egyfelől a migrációs képességet korlátozó strukturális kényszerek, másfelől a helyben maradás iránti vágyak ${ }^{23} \mathrm{fe}$ lől kívánja értelmezni. A migrációs törekvések és képességek fogalompár a mig- 
rációkutatásban nem új, Carling érdeme, hogy az immobilitás vonatkozásában gondolta újra őket. Zöld-foki-szigeteken végzett kutatásainak eredményeként alkotta meg a kényszerü immobilitás (involuntary immobility) fogalmát, amely a migrációra vágyó, ám arra strukturális kényszerek (zárt határok, szigorodó bevándorláspolitikák, szelektív migrációs rezsimek) miatt nem képes emberek helyzetét ragadja meg (Carling 2002). Míg a migráció Carling szerint feltételezi, hogy az ember törekszik a migrációra és rendelkezik is az ehhez szükséges képességekkel, addig az immobilitás valamelyik hiányát feltételezi. Az önkéntes immobilitás (voluntary immobility) ${ }^{24}$ azt jelenti, hogy az érintettek el tudnának indulni, hiszen képesek rá, mégsem törekszenek erre.

Ezt a modellt fejlesztette tovább Hein de Haas, aki az ability fogalmát Amartya Sen fejlődéskoncepciójától inspirálva, a capability fogalmára cserélte (de Haas 2014). Sen szerint a fejlődés olyan folyamatnak is tekintheto", amelynek során bövül az emberek szabadsága, és ennek köszönhetően olyan dolgokat tehetnek, olyan életet élhetnek, amelyet értékesnek tartanak (Sen 2003). De Haas számára az a kérdés, hogy a migráció során bővül-e az emberek szabadsága, növekszik-e a képességük arra, hogy az általuk értékesnek tartott értéket éljék, a saját életüket ellenőrizzék (de Haas 2009; lásd még Németh, Váradi 2018; Váradi et al. 2017; Váradi 2018). Noha az ability és capability fogalmait alapvetően szinonimaként használják, ${ }^{25}$ utóbbi magába foglalja az emberi szabadság dimenzióját és így az emberi jogok problémáját is, és összekapcsolja az immobilitást a fejlődés problémájával (Schewel 2019, lásd még Erőss 2020).

Schewel szerint mind Carling, mind de Haas kevés figyelmet szentel az önkéntes immobilitásnak, előbbi a migrációs rezsimek által teremtett immobilitásra figyel, utóbbi a migrációra fókuszál. Ezért bevezeti a modellbe a belenyugvó/ elfogadó immobilitás (acquiescent ${ }^{26}$ immobility) fogalmát arra az esetre, amikor a migráció/mobilitás szándéka és képessége egyaránt hiányzik (Schewel 2015, 2019; Carling, Schewel 2018, lásd még Erőss 2020). Schewel e fogalom bevezetésével meg kívánta kérdőjelezni azt a neoklasszikus migrációelméleti feltételezést, amely szerint a migrációs aspirációk és a szegénység szintje között egyenes vonalú az összefüggés. Saját, szenegáli kutatásai során azt tapasztalta, hogy azok a szegények, akik a legnagyobb megélhetési gondokkal küszködnek, és akik tisztában vannak azzal, hogy a migráció egy lehetséges megélhetési stratégia lenne számukra, még csak a gondolatával sem játszottak el, és vágyaik horizontján vagy döntéseikben sem jelent meg soha az, hogy elinduljanak (Carling, Schewel 2018, 956-957.). A legnagyobb szegénységben élők egyben aspirációs csapda (Appadurai 2004) foglyai is, életkörülményeiken, szegénységükön képtelenek változtatni, és lehetőségek, perspektívák hiányában a vágyakozás, törekvés képessége sem alakul ki bennük (lásd még Czaika, Vothknecht 2014; de Haas 2014). Az aspirációk hiánya azonban értelmezhető az adaptív preferenciák fogalmával is (Carling, Schewel 2018, 958.). A strukturális viszonyok eleve nem teszik lehetővé a mobilitási képességek kialakulását, ezért az érintettek, egyfajta pszichológiai védekező me- 
chanizmusként, elfogadják, természetesnek tekintik immobilitásukat, amit így nem szégyenként, kudarcként, hanem jóllétük, biztonságuk forrásaként élnek meg (Carling, Schewel 2018, 958.).

Egy új hazai kutatás eredményei alapján ${ }^{27}$ a belenyugvó/elfogadó immobilitás példájaként azonosítható sok, szegénységben, kirekesztettségben élő falusi fiatal története, mobilitáshoz való viszonya (lásd Czibere 2019; Csoba 2019; Nagy 2019). Említhetem azonban azokat a közfoglalkoztatottakat is, akik néhány éve egy csoportos beszélgetés során arra a kérdésre, vajon gondolkoztak-e azon, hogy ők is külföldre menjenek dolgozni, sorra említették mások kudarccal végződött próbálkozásait, annak alátámasztására, hogy nekik miért nem jut az eszükbe, hogy elinduljanak. A beszélgetés közben fény derült arra, hogy nem is rendelkeznek olyan erőforrásokkal (elsősorban kapcsolatokkal, segítö-támogató hálózatokkal), amelyek segítségével képesek lennének mobilitásra, ezekről azonban nem (im)mobilitási aspirációikkal összefüggésben beszéltek.

Éppen a belenyugvó/elfogadó immobilitás fogalma mutat rá arra, hogy a strukturális korlátok hatását nem csak az (im)mobilitási képességek vonatkozásában értelmezhetjük, hiszen azok az emberek vágyait, jóllétről alkotott elképzeléseit, jövőhorizontját is alakítják, ugyanakkor az emberek ágenciája sem hagyható figyelmen kívül, hiszen minden (im)mobilitásra irányuló döntésben egyszerre van jelen a kényszer és a választás. Az emberek aspiráció és képességei nem eleve meglévő adottságok, változ(hat)nak az idővel. Ahogy nehéz éles határvonalat húzni kényszerű és önkéntes mobilitás/migráció között, úgy az immobilitás modelljeit sem merev kategóriákként, hanem egy kontinuum mentén elhelyezkedő ideáltípusokként foghatjuk fel (Cresswell 2010a; de Haas 2010, 2014; Schewel 2015, 2019; Carling, Schewel 2018).

\section{Az immobilitás értelmezései}

Az aspiráció és képesség modellje alkalmas az immobilitás típusainak azonosítására, de arra a kérdésre nem válaszol, hogy az emberek végül is miért részesítik előnyben a helyben maradást, az immobilitást - akár önként választják azt, akár elfogadják helyzetüket. Kerilyn Schewel három kategóriát vezet be, amelyek segítenek a kérdés megválaszolásában (2019, 11-17.). A mobilitást/migrációt magyarázó taszító és vonzó (push and pull) tényezők mintájára megkülönbözteti a megtartó (retain) és a visszatartó (repel) tényezőket, harmadikként pedig a belső akadályokat (internal constraints) nevezi meg, amelyek az immobilitás melletti döntést, illetve annak magától értetődő, természetes mivoltát együttesen értelmezhetővé teszik. Ezek a faktorok természetesen az esetek többségében szétbogozhatatlanul összefonódnak, megkülönböztetésük analitikus szempontból mégis fontos (az immobilitást meghatározó tényezők összetettségéhez lásd például Mata-Codesal 2015, 2018; Csoba 2019; Erőss 2020). 
Az embereket helyben megtartó faktorok között talán az a legmeghatározóbb, amelyet Fischer és szerzőtársai „bennfentes előnyöknek” ('insider advantage') neveznek (Fischer et al. 2000; Hjälm 2014; Schewel 2019, 12-13.). A helyhez kapcsolódó anyagi és társadalmi tőkék, hasznok helyben tarthatják az embereket, családokat, ezek ugyanis elveszhetnek egy esetleges helyváltoztatással. Ezek az előnyök szorosan összefüggenek az érintettek beágyazottságával a lokalitásba, ami természetesen erősödik az életkorral, a helyben töltött (akár generációkra visszanyúló) idővel, a társas kapcsolatok hálójával és az intézményes kötődésekkel. A lokális erőforrásokhoz való hozzáférés tehát valószínűsíti a maradás melletti döntést, az immobilitást (lásd még Mata-Codesal 2015, 2018). Saját korábbi és jelenlegi kutatásaink valamint más vizsgálatok tapasztalatai is alátámasztják ezt a tézist; a jól fizetett munka, a családi vállalkozás, a gazdálkodás lehetősége, a társadalmi megbecsültség és presztízs, valamint az ezekhez kötődő jövőbeli kilátások az immobilitás/helyben maradás vágyát erősítik (Csoba 2019; Krémer 2019; Váradi 2016). Ahogy a földrajzi mobilitás együtt járhat a társadalmi mobilitással, vagy annak reményével (lásd Durst 2018a, b), úgy az immobilitás is vágyott életstratégia lehet, ha a helyben maradás a társadalmi mobilitás ígéretét hordozza (Mata-Codesal 2015, 2018).

A visszatartó tényezőket leginkább a mobilitás lehetséges célterületeihez, a központokhoz, városokhoz, a külföldhöz, az ott kínálkozó életkörülményekhez és lehetőségekhez tapadó negatív, taszító tudások, vélemények, vélelmek, képzetek alkotják. A már elvándorolt családtagoktól, barátoktól, ismerősöktől érkező, a médiában megjelenő hírek, információk a nehézségeket és veszélyeket hangsúlyozhatják, s ezek félelmet kelthetnek az emberekben a mobilitással járó esetleges (anyagi, társadalmi, kulturális, morális) veszteségektől, kudarcoktól vagy a fenyegetőnek tartott erőszaktól (Schewel 2019, 14-15., lásd még Hanson 2010; Nagy 2019).

A megtartó és a visszatartó erők hatása elválaszthatatlan attól az alapvető emberi szükséglettől, hogy tartozzunk valahová, otthon és biztonságban érezzük magunkat a minket körülvevő világban. A „kötődés lehatárolt tere" ('bordered space of belonging') a lokalitás, a táj, a régió, a nemzetállam egyaránt lehet, e terek és a hozzájuk kapcsolódó érzetek, érzelmek egyúttal az itthon és a külföld, a falu és a város, a „mi” és az „ők” közötti különbségeket, határvonalakat is kijelölik. Az otthon, a haza konstruált képzetei, a hozzájuk tapadó tudások, hitek, kötődések eleve közömbössé tehetik az embert más helyekkel, a külfölddel, a migráció lehetőségével szemben (van Houtum, van der Velde 2004; van Naerssen, van der Velde 2015; Silvey 2004). A leghátrányosabb helyzetben élő közösségekben is megtartó erőt (s egyben erőforrást) jelenthet a kötődés az otthonhoz, családhoz, szomszédsághoz, kortárs csoporthoz, a lokalitáshoz (lásd Huszti 2019; Kerülő 2019; Molnár 2019). A szülőföldhöz, hazához füződő spirituális kötődés, a szülőföldön való boldogulás morális parancsa is magától értetődővé teszi az immobilitást mint a jó élet lehetőségét (Róin 2015; Schewel 2015). Az immobilitás aspirációját erősítő megtar- 
tó és taszító erők, belső akadályok is csak arra mutatnak rá, hogy az emberek (im)mobilitási aspirációi nem pusztán anyagi természetủ megfontolásokból táplálkoznak (Schewel 2019, 16.).

Az (im)mobilitási aspirációk, a hozzájuk kötődő narratívák nagymértékben függenek az érintettek életkorától és nemétől (Mata-Codesal 215, 2018; Schewel 2019). Minél hosszabb időt tölt el valaki szülő- vagy lakóhelyén, annál valószínűbben immobil, annál kevésbé hajlik migrációra, ám az immobilitás még idős korban is feltételezi az ágenciát, a változó lakókörnyezethez való aktív alkalmazkodást (Fischer et al. 2000; Hjälm 2015; Róin 2015).

Annak ellenére, hogy a nők mindig részt vettek a migrációban, a női migráció és mobilitás kutatása sokáig háttérbe szorult, a nők mobilitása láthatatlan maradt vagy a passzív - a férfiakat követő - szerepre kárhoztatták őket (lásd áttekintően Carling 2002; Lutz 2010; Mahler, Pessar 2006). Mindez szorosan összefügg azzal, hogy mobilitás és immobilitás, a tér és a hely felfogásával és értelmezésével együtt, a hagyományos gender ideológiák sarokkövét jelentette (Hanson 2010, 9.). Eszerint a nők az otthon privát, intim tereiben mozognak, mobilitásuk a mindennapi, családi rutinokkal függ össze, míg a férfiak az otthon falain kívül, a nyilvános terekben, adott esetben nagy távolságokat bejárva mozognak (Hanson 2010; Cresswell, Uteng 2008; Cresswell 1999). Tisztában vagyok azzal, hogy (im)mobilitás és gender kölcsönös meghatározottsága és viszonya külön tanulmányt igényel, ezért a fejezet végén csak két fontos összefüggésre hívnám fel röviden a figyelmet.

Éppen a mobilitás és immobilitás, a nyilvános és privát szembeállítása és összekapcsolása a maszkulinitással és feminitással volt az oka annak, hogy feminista kutatók a nők mobilitását önmagában a szabadság, önkiteljesedés eszközének tekintik. Mások ugyanakkor arra figyelmeztetnek, hogy a mindenkori társadalmi, kulturális és térbeli kontextuson múlik, hogy a nők privát térbe való visszahúzódása, immobilitása mennyire választás vagy kényszer eredménye, ennek megértéséhez pedig meg kell tudnunk, hogy az érintettek számára mit jelent (im)mobilitásuk, hogyan élik meg és értelmezik azt. Másként fogalmazva, mobilitás és immobilitás kiteljesedést és elnyomást egyaránt jelenthet a különböző kontextusokban, ebből következően a privát tér is lehet az ellenállás és az ágencia tere (Hanson 2010; Cresswell 1999; Cresswell, Uteng 2008; Ní Laoire 2001).

Mindennapos tapasztalat, hogy a nők (im)mobilitását nem egyszer meghatározzák a velük szemben támasztott hagyományos normák és elvárások (Schewel 2019, 16.), ezt azonban nem feltétlenül ágenciájuk korlátozásaként élik meg az érintettek. Egy falusi, hosszú évek óta közfoglalkoztatásban dolgozó asszony például arról beszélt, hogy férje „nem engedi” más, távolabbi településre dolgozni, jobban szereti őt itthon, biztonságban tudni. Ez a fiatalasszony számára a kettejük közötti erős szeretet kifejeződése.

(Im)mobilitás és társadalmi nem viszonyára nem csak női perspektívából tekinthetünk. Caitríona Ní Laoire például az írországi rurális terekben élö férfiak 
gyakori öngyilkossága és immobilitása közötti összefüggést vizsgálta. Elemzésében bemutatja, hogy a kvalifikálatlan, a családi birtokot átvevő férfiak immobilitása és szuicid hajlandósága miként függ össze a nők térbeli és társadalmi mobilitási aspirációival és elvándorlásával, az agrárgazdaság strukturális átalakulásával, az erősödő vidéki munkanélküliséggel, s hogy mindezek a folyamatok miként roppantják meg a maszkulin identitást, amelynek központi eleme a biztos, fizetett munka és a saját maguk és a környezetük feletti kontroll képessége (Ní Laoire 2001).

Hazai példával zárva e gondolatmenetet, az elmúlt években az elsődleges munkaerőpiacra történt jelentős kiáramlás mellett is maradtak olyan jellegzetes csoportok, amelyek „beragadtak” a közfoglalkoztatásba. A munkaerőpiaci immobilitás természetesen szorosan összefügg a közfoglalkoztatottak alacsony iskolai végzettségével, hiányzó vagy megkopott munkavégző képességével, a közfoglalkoztatásban eltöltött idő hosszával, tehát alapvető strukturális és magából a programból fakadó tényezőkkel. Ugyanakkor a terepkutatások két markáns csoportot azonosítottak a munkaerőpiaci szempontból immobil közfoglalkoztatottak között. Az egyik az idősebb, többféle egészségügyi problémával, függőségekkel küszködö, gyakran egyedülálló (elvált, magukra maradt) férfiak csoportja, akik már nem keresettek az elsődleges munkaerőpiacon és maguk is elfogadják, véglegesnek tekintik immobil helyzetüket. A közfoglalkoztatásban maradó nők között azonban többen élethelyzetük miatt nem tudják összeegyeztetni otthoni, gondozási, ápolási feladataikat a számukra elérhető (többműszakos, az otthontól huzamosabb távollétet jelentő) munkalehetőségekkel (Koltai 2018). Jelenleg folyó kutatásunk során viszont az is nyilvánvalóvá vált, hogy az asszonyok „beragadása" a közfoglalkoztatásba, munkaerőpiaci immobilitása nem egyszer egy olyan családi megélhetési stratégia része, amely a „bennfentes előnyökre” épít, s az asszonyok közfoglalkoztatásban való részvétele lehetővé teszi például a családi gazdaság igényeihez alkalmazkodó, rugalmas munkavégzést. Ha néha felmerül is az elköltözés vágya, gondolata, részben a helyi erőforrásokhoz való hozzáférés az, amely helyben tartja a családokat. Emellett azonban a mobilitási vágyakat mérsékli az a belátás, hogy az ingatlanpiac területi egyenlőtlenségei eleve korlátozzák a családok mobilitási képességét. A nők közfoglalkoztatásban való részvétele továbbá érdeke azoknak a sérülékeny helyzetű családoknak is, amelyek megélhetési stratégiáikat a bérmunka, az alkalmi és informális munka valamint a közfoglalkoztatás akár egyidejü váltogatására építik (Kovai, Vigvári 2020).

\section{Összegzés}

A szűkebb kutatási kérdésünktől való szakirodalmi „elkalandozás” hozadéka az lehet, hogy tágabb elméleti, szemléleti, értelmezési keretet és kapcsolódási lehetőséget kínál a magyar vidéki mobilitás és immobilitás különböző típusainak ku- 
tatásához, mind az eddigi eredmények (újra)olvasását illetően, mind jövőbeni kutatási projektek számára.

Az „új mobilitási paradigmához” kapcsolódó és az immobilitás kutatásának jelentősége mellett érvelő szerzők (számomra inspiráló) munkái alapján fontosnak tartom a mobilitás és immobilitás holisztikus és relacionális, az (im)mobilitás különböző típusainak kölcsönhatására, dinamikájára, mintázatainak változásaira és együttállásaira figyelő megközelítését - egyéni, családi és közösségi (lokális) kutatási és elemzési szinten egyaránt. Azt is alapvető, mindig szem előtt tartandó belátásnak tartom, hogy az (im)mobilitáshoz való hozzáférés, az (im)mobilitási aspirációk és képességek eloszlása egyenlőtlen globálisan éppen úgy, mint egyes társadalmakban. Ebből következően az egyik kutatási kérdés mindig az, hogy az egyenlőtlenségeket (újra)termelő gazdasági, társadalmi, politikai, kulturális, hatalmi struktúrák miként alakítják az (im)mobilitás esélyeit és lehetőségeit az emberek osztályhelyzete, nemzeti, etnikai hovatartozása, társadalmi neme, lakóhelye, életkora, egészségi állapota mentén. A strukturális folyamatok, intézmények, rezsimek támogató és gyakrabban korlátozó hatásai mellett sem - legfeljebb nagyon szélsőséges esetekben - beszélhetünk azonban az emberi ágencia, az emberek választási, döntési, cselekvési képességének és lehetőségének teljes visszaszorulásáról. Az (im)mobilitási aspiráció és képesség modellje alapján megalkotott típusok struktúra és ágencia kölcsönhatásait bontják ki és értelmezik egyfajta módon, ugyanakkor arról nem adnak információt, hogy az emberek végül is miért vágynak, törekszenek (im)mobilitásra. A kényszerü, önkéntes, vágyott vagy elfogadott immobilitást magyarázó tényezők közelebbi vizsgálata nem csak arra mutat rá, hogy a megtartó, visszatartó és belső korlátozó tényezőket nehéz empirikusan szétválasztani, de arra is, hogy ami kutatói szemmel kényszerű csapdahelyzetnek látszik, az az érintettek megélhetési és alkalmazkodási stratégiái szempontjából kulcsfontosságú lehetőségekhez való hozzáférést jelenthetik. Az (im)mobilitás kutatása szempontjából (is) alapvető kutatási feladat az érintett (im)mobil emberek saját hangjának megszólaltatása, megélt tapasztalataik megértése.

\section{Jegyzetek}

1 A (köz)foglalkoztatás és (im)mobilitás (2018-2020) című kutatás témavezetői Molnár György (KRTK KTI, kvantitatív kutatási feladatok országos adatbázis alapján) és Váradi Monika Mária (KRTK RKI, kvalitatív kutatás). A különböző vidéki terepüléseken (egy nagyvárosban, két kisvárosban és három községben) végzett kvalitatív kutatásban részt vesz Kovai Cecília, Németh Krisztina és Vigvári Andás.

2 Az új mobilitási paradigmáról John Urry elméleti munkásságát bemutatva Berger Viktor írt összefoglalót nemrég megjelent könyvében (Berger 2018, 167-169.), amelynek magyar fogalomhasználatára magam is támaszkodom.

3 „A szedentarizmus normálisnak tartja az állandóságot, a közelséget és a meggyökerezettséget, és abnormálisnak tekinti a távolságot, a változást és a helynélküliséget” (Sheller, Urry 2006, 
208.). A szedentarizmust gyakran kötik Heideggerhez, aki számára a wohnen (lakni egy helyen) koncepciója a folyamatos, nyugalmas, békés tartózkodást, az otthonnal való elégedettséget jelenti (Sheller, Urry 2006, 208.).

4 Éppen e szöveg írása közben, a koronavírus terjedésével a szemünk láttára bontakozik ki egy olyan válság, amely valószínűleg hosszú távon is nagy hatással lesz a globális mobilitási mintázatokra, gyakorlatokra.

5 A paradigma fogalma nem feltétlenül szerencsés, normativitása ugyanis arra utal, mintha a szedentarizmus a normálistól való eltérés lenne (Merriman et al. 2008, 198.), másfelől azt a téves feltételezést sugallja, hogy a mobilitás a modern, posztmodern világgal jelent meg, mintha a korábbi történelmi korszakok társadalmait az immobilitás jellemezte volna. Az emberek és a dolgok azonban mindig is mozgásban voltak, és a mobilitás korábban is fontos kutatási kérdés volt a társadalomtudományok, mindenekelőtt a földrajz számára (Cresswell 2010 a,b; Sheller 2013).

Cresswell a kilencvenes évekbeli előzmények között említi Marc Augé gondolatait az olyan „nemhelyekről”, mint a repülőterek vagy autópályák, az antropológus James Clifford munkáját az utazó népek helyeket összekötő útvonalairól, Manuel Castells hálózati társadalomról alkotott elméletét vagy a feminista perspektívát képviselő Caren Kaplan munkáját a mobilitásról (Cresswell 2010b, 551.). Az új mobilitási paradigma elméleti előzményeiről és kapcsolódásairól lásd még Sheller, Urry 2006, valamint Adey 2006.

7 Tim Cresswell egy 2012-ben rögzített beszélgetésen a „mobilitási fordulat” felütéseként John Urry Sociology beyond Societies (2000) című könyvének megjelenését, illetve a New Formations című folyóirat 2001-es, mobilitásról szóló különszámát (amelyet maga Cresswell szerkesztett) nevezte meg. A mobilitási kutatási irány népszerűségének gyors terjedését és intézményesülését jelzi a Mobilities (2006) és a Transfer (2011) című folyóiratok alapítása, valamint a Mobilitások Kutatási Centrum Urry és Sheller nevéhez kötődő indítása a Lancaster University intézményi keretein belül (lásd Merriman et al. 2013).

8 A közlekedésföldrajz vagy a migrációkutatás a mobilitás egy-egy típusára fókuszál, mi több, a migráció elméletei igazából a helyekről s nem magáról a mozgásról szólnak (Cresswell 2010a).

9 A paradigmát érintő kritikák problematikusnak tartják, hogy ez a szemlélet a mobilitás fetisizálását és a „minden áramlik” diskurzus elterjedését eredményezi (Canzler, Kaufmann, Kesselring 2008,2.). Az új mobilitási paradigmát meghirdető, üdvözlő kutatók is óvatosságra intenek. Hangsúlyozzák, hogy a szedentarizmust éppen úgy kritikával illetik, mint a „deterritorializált” megközelítéseken alapuló „nagy narratívákat”, amelyek a mobilitást, a fluiditást vagy cseppfolyóságot a posztmodernitás vagy globalizáció mindenütt jelenlévő feltételének tartják (Sheller, Urry 2006, 210;; Hannam, Sheller, Urry 2006, 5.; Sheller 2013).

10 A repülőtér, ,,az új világrend ikonikus tere” (Sheller, Urry 2006, 219.) kínálja magát az új mobilitási paradigma, az áramlás és megállás, a nyugalom és mozgás, a stabilitás, rögzítettség és mobilitás kölcsönös viszonyrendszerének szemléltetésére és elemzésére. Míg Marc Augé a repülőteret a nemhelyek közé sorolja, ,ahol az emberek együtt léteznek vagy időznek, anélkül, hogy együtt élnének" (Augé 1995,110., idézi Sheller, Urry 2006, 219.), a mobilitási szemlélet a repülőtereket az átkelés olyan helyeinek tekinti, amelyeken keresztül az emberek és a tárgyak globális viszonyokba lépnek; tér és idő sűrűsödésének terei. A repülőterek nem üres helyek, gépek, technikák és emberek szervezett napi cselekvései müködtetik, s a nagy repülőterek kisebb várost jelentenek az ott dolgozók számára (Sheller, Urry 2006, 219.; Berger 2018, 168.)

11 A nomád metafizika fogalma (Cresswell 2001) azokat a megközelítéseket jelöli, amelyek szerint a mobilitás a hatalmi struktúrák anyagi és szimbolikus értelemben vett áthágásának eszköze (Adey 2006, 77.).

12 A mobil kutatási módszertanok része az emberi mozgások és találkozások megfigyelése. A mobil etnográfia azt jelenti, hogy a kutató maga is részt vesz a vizsgált csoportok mobilitásában. Gyakori hogy a kutatásban résztvevőkkel naplót íratnak, amelyekben a napi mozgásokat rögzítik. A „kiberkutatás” az emberek virtuális és képzeletbeli mobilitásait követi webes csoportokban, míg az imaginárius utazás egy-egy hely atmoszféráját, élethelyzet sajátosságait tárja fel, például a szépirodalom segítségével, továbbá ide sorolható az utazások, mobilitások emlékeinek kutatása is (lásd Sheller, Urry 2006, 217-219.; Berger 2018.168-169.). 
13 A szerzők szerint a modern társadalmakban jelenik meg a mobilitás és a változás közötti pozitív kapcsolat. Példaként említik Johann Wolfgang Goethe Utazás Itáliában című művét, amelyben megjelent a mobilitás modern koncepciója; a római utazás célja a szerző személyiségének változása. „Ez az az eszme, ami a térbeli mozgásra a társadalmi helyzet megváltoztatásának útjaként, bizonyos projektek, tervek megvalósításának eszközeként tekint” (Canzler, Kaufmann, Kesselring 2008, 3.).

14 Canzler, Kaufmann és Kesselring szerint a mozgás és a mobilitás szinonim jelentéseinek feloldása három dimenzióban lehetséges. (1) Az ember mozoghat anélkül, hogy mobil lenne, vagyis a térbeli mozgás nem jelent változást az érintett szereplők helyzetében. Erre példaként szolgálhatnak a világ konferenciahoteljei között ide-oda repkedő üzletemberek, akiknek mégoly gyakori mozgása nem jár társadalmi mobilitással, nem eredményez kapcsolatokat más környezetekkel, valóságokkal. (2) Valaki lehet mobil a nélkül is, hogy mozgásban lenne. Példaként felidézhetjük mindazokat, akik sokat és intenzíven használják a nagy távolságokat áthidaló kommunikációs eszközöket: internetet, email-t vagy skype-ot, s akik így a sajátjuktól eltérő társadalmi valóságokkal lépnek érintkezésbe. De gondolhatunk azokra is, akik egy könyvet olvasva belemerülnek egy másik világba. (3) Az ember mozoghat és mobil is lehet, vagyis a földrajzi terek közötti mozgás egyúttal különböző társadalmi terek átlépését is jelenti. Ez a szociológiában jól dokumentált példa a territóriumokhoz kötött és hierarchikus társadalmak létezését feltételezi (Canzler, Kaufmann, Kesselring 2008, 4.).

15 Nem nehéz észrevenni a hasonlóságot a motilitás és a migrációs képesség (migration ability/ capability) fogalmai között (lásd Carling 2002; de Haas 2014; Carling, Schewel 2018; Schewel 2019). A mozgásra való képességként definiált motilitás, az érintett szereplő szándékainak függvényében éppen úgy irányulhat mobilitásra, mint immobilitásra (Canzler, Kaufmann, Kesselring 2008, 5.).

16 John Urry (2002) a mobilitás és társadalmi tőke viszonyát elemezve vitatkozik Robert Putman Bowling Alone címü könyvének állításával, noha Putman nem foglalkozik kifejezetten a mobilitással. A könyv azt mutatja be, hogy a társadalmi betagozódás (inclusion) a társadalmi tőke komplex, gazdag és többrétegű formáin alapszik. Putman szerint az amerikai társadalomban az emberi együttlétek a hatvanas évek óta veszítenek jelentőségükből, a telefon és az internet használata, csakúgy, mint a sok idővel járó ingázás, autózás erodálják az emberi kapcsolatokat, tehát a társadalmi tőke gyengüléséhez vezetnek. Urry alapvetően elhibázottnak tartja ezt az érvelést, amely nem veszi figyelembe az amerikai várostervezés sajátosságait, a funkciók (lakás, munkahely, kereskedelem, rekreáció) zónaszerű tervezését és elhelyezését, ami elengedhetetlenné teszi az autós közlekedést, azt, hogy a kortárs amerikai életforma még a kisebb városok esetében is extenzív mobilitást követel az emberektől. Ahogy arra sincs figyelemmel, hogy akár a tudományos, akár a családi kapcsolatok fenntartása is nemzetközi mértékủ mobilitást feltételez.

17 Egy évekkel ezelőtt, több aprófalvas településszerkezetű térségben végzett kutatásunk eredményeit bemutató tanulmánykötet alaposan dokumentálja a mobilitás hiányának e metszetét (lásd Váradi 2018 tanulmányait).

18 A már említett 2008-as beszélgetésen Mimi Sheller amellett érvelt, hogy a mobilitáskutatásoknak a jövőben két fontos kérdést kell hangsúlyosabbá tenniük. Az egyik a fenntartható mobilitás problémája, az áttérés az autós közlekedésről a mobilitás más formáira, például a kerékpározásra vagy gyaloglásra, ami a várospolitikák számára kulcskérdés. A másik a társadalmi egyenlőtlenségek és a mobilitás egyenlőtlen elosztásának problémája, amit Sheller „a mobilitáshoz kapcsolódó igazságtalanságnak" ('mobility injustice') nevez (Merriman et al. 2013,156-157.).

19 A testté vált gyakorlat (embodiment) arra a folyamatra utal, amelyben az egyedi test a legkülönbözőbb léptékekben a jelentések tágabb hálózataihoz kapcsolódik, és arra, ahogy a külső erők hatása alatt álló testen keresztül és a test által társadalmi és kulturális kapcsolatok jönnek létre (Cresswell 1999,176.).

20 Megint csak utalhatunk a hasonlóságra de Haas elméletével ágencia és struktúra migrációs folyamatokban játszott szerepéről (de Haas 2014, magyarul összefoglalóan Váradi 2018). 
21 A mobilitás politikájának különböző dimenzióira Cresswell gyakran a repüléssel kapcsolatos egyenlőtlenséget teremtő gyakorlatokat hoz példaként (ki milyen gyorsan jut a repülőgépre, milyen osztályon utazhat s ott milyen szolgáltatásokban van része stb.), s gyakran idéz történelmi példákat. Élvezetes olvasni a sétához kapcsolódó jelentések változásáról, arról, hogy a romantikus költők megjelenése előtt a gazdagok szemében a séta, a gyaloglás a szegények, csavargók, bűnözők stb. sajátja volt, míg aztán a pihenés, a szemlélődés útjává vált, természetesen nem a szegények számára.

22 A szakirodalomban különböző fogalmakat alkalmaznak azokra, akik nem migrálnak: nem-migránsok (non-migrants), maradók (stayers), hátrahagyottak (left-behind), immobilak. E fogalmak mindegyike a mobilitáshoz való sajátos viszonyt és jelentést implikál (Jónsson 2011). MataCodesal a helyben maradni (staying put) kifejezést ajánlja (Mata-Codesal 2015). A legsemlegesebbnek és leginkább rugalmasnak az immobilitás fogalma tekinthető (Schewel 2019, lásd még Erőss 2020).

23 A migrációs aspirációk szinonimáiként használják a preferenciák, szándékok (wishes) és vágyak (desires) fogalmakat is (Carling, Schewel 2018; Schewel 2019), ennek megfelelően egymással felcserélhető fogalmakként használom őket magyarul is.

24 Mata-Codesal (2018) az aspiráció és képesség modelljéhez kapcsolódva az önkéntes szinonimájaként használja a vágyott (desired) immobilitás kifejezést.

25 Magyarul mindkettő képességet jelent.

26 A fogalom latin gyökerének jelentése „nyugodtan maradni” ('to remain at rest') (Schewel 2015, 2019).

27 A hátrányos helyzetű vidéki településeken élő fiatalok immobilitására fókuszáló kutatás az MTA KEP Mobilitás Kutatási Centrum keretében és támogatásával valósult meg. Az eredményeket bemutató tanulmányok a Metszetek 2019/3-as számában jelentek meg. Ha nem is a mobilitási paradigma fogalmi keretein belül, de hasonló szemléletű, a különböző, földrajzi és társadalmi (im)mobilitásokat figyelembe vevő és egymásra vetítő leírások és elemzések olvashatók a lapban.

\section{Köszönetnyilvánítás}

A tanulmány megírását a Magyar Tudomány Akadémia Kiválósági Együttműködési Program (MTA KEP) Mobilitási Kutatási Centrum programja és támogatása tette lehetővé.

\section{Irodalom}

Adey, P. (2006): If Mobility is Everything Then it is Nothing: Towards a Relational Politics of (Im)mobilities. Mobilities, 1., 75-94. https://doi.org./10.1080/17450100500489080

Adey, P. (2017 [2010]): Mobility. Second Edition. Routledge, London and New York

Appadurai, A. (2004): The Capacity to Aspire: Culture and the Terms of Recognition. In: Rao, V. and Walton, M., (eds.) Culture and Public Action, Stanford University Press, Palo Alto, California, 59-84.

Augé, M. (1995): Non-places. Verso, London, idézi Sheller, Urry 2006

Bell, M. M., Osti, G. (2010): Mobilities and Ruralities: An Introduction. Sociologica Ruralis, 3., 199-204. https://onlinelibrary.wiley.com/doi/epdf/10.1111/j.1467-9523.2010.00518.x

Berger V. (2018): Térré szőtt társadalmiság. A tér kategóriája a szociológiaelméletekben. L'Harmattan - Könyvpont, Budapest

Canzler, W., Kaufmann, V., Kesselring, S. (2008): Tracing Mobilities - An Introduction. In: Tracing Mobilities - towards a cosmopolitan perspective. Routledge, London, New York http://www.ashgate.com/SamplePages/Tracing_Mobilities_Intro.pdf (Letöltés 2019. 05. 21.)

Carling, J. (2002): Migration in the age of involuntary immobility: theoretical reflections and 
Cape Verdean experiences. Journal of Ethnic and Migration Studies, 1., 5-42. https://doi.org/ $10.1080 / 13691830120103912$

Carling, J. (2005): Gender Dimensions of International Migration. Global Migration Perspectives No. 35. Global Commission on International Migration, Geneve https://www.researchgate.net/publication/238781225_Gender_Dimensions_of_International_Migration (Letöltés: 2020. 02. 28.)

Carling, J., Schewel, K. (2018): Revisiting aspiration and ability in international migration. Journal of Ethnic and Migration Studies, 6., 945-963. https:doi.org/10.1080/1369183X2017.1384146

Cresswell, T. (1999): Embodiment, Power and the Politics of Mobility: The Case of Female Tramps and Hobos. Transactions of the Institute of British Geographers, New Series, 2., 175-192. https:// jstor.org/stable/623295 (Letöltés: 2019. 08. 15.)

Cresswell, T. (2001): The production of mobilities. New Formations, 1., 11-25., idézi Adey 2006

Cresswell, T. (2010a): Towards a politics of mobility. Environment and Planning D: Society and Space, 28., 17-31. https://doi.org/10.1068/d11407

Cresswell, T. (2010b): Mobilities I: Catching up. Progress in Human Geography, 4., 550-558. https:// doi.org/10.1177/0309132510383348

Cresswell, T. (2012): Mobilities II: Still. Progress in Human Geography, 5., 645-653. https://doi.org/ 10.1177/0309132511423349

Cresswell, T., Uteng, T. P. (2008): Gendered Mobilities: Towards an Holistic Understanding. In: Uteng, T. P., Cresswell, T. (eds): Gendered Mobilities. Ashgate, Aldershot https://citeseerx.ist.psu.edu/ viewdoc/download?doi=10.1.1.529.89568\&rep.=rep181\&type=pdf (Letöltés: 2019.07 .12 .)

Csoba J. (2019): Hol dolgoznak a falusi fiatalok? Kötődéstípusok és foglalkozási karakterek a kistelepülésen élő fiatalok körében. Metszetek, 3., 55-85. https://doi.org/10.18392/metsz/2019/3/3

Csurgó B. (2007): Képek és képzetek a mai magyar vidékről. In: Kovách I. (szerk.): Vidékiek és városiak. A tudás- és imázshasználat hatásai a vidéki Magyarországon. L'Harmattan Kiadó, Budapest, 45-67.

Csurgó B. (2013): Vidéken lakni és vidéken élni. A városból vidékre költözők hatása a vidék átalakulására. Argumentum, MTA TK SZI, Budapest

Czaika, M., Vothknecht, M. (2014): Migration and aspirations - are migrants trapped on a hedonic treadmill? IZA Journal of Migration 3:1. http://www.izajom.com/content3/1/1 (Letöltés 2016. 03. 21.)

Czibere I. (2019): Az alacsony státuszú, szegénységben élő falusi fiatalok immobilitásának okai. Metszetek, 3., 133-152. https://doi.org/10.18392/metsz/2019/3/7

Czibere I., Kovách I. (2019): Községekben élő immobil fiatalok. Metszetek, 3., 3-22. https://doi.org/ $10.18392 / \mathrm{metsz} / 2019 / 3 / 1$

de Haas, H. (2009): Mobility and Human Development. Human Development Research Paper 2009/1. United Nations Development Programme Human Development Report, http://mpra.ubi-nuebchen.de/19176/ (Letöltés: 2016. 05.21.)

de Haas, H. (2010): The Internal Dynamics of Migration Processes: A Theoretical Inquery. Journal of Ethnic and Migration Studies, 10., 1587-1617. http://dx.doi.org/10.1080/1369183X.2010.489361

de Haas, H. (2014): Migration Theory. Quo Vadis? IMI Working Papers, No. 100, International Migration Institute, University of Oxford. https://www.imi.ox.ac.uk/publications/wp-100-14 (Letöltés: 2016. 06.01.)

Durst J. (2008): „Bárók”, patrónusok versus „komák” - Eltéro fejlődési utak az aprófalvakban. In: Váradi M.M.(szerk.): Kistelepülések lépéskényszerben. Új Mandátum Kiadó, Budapest, 232-267.

Durst, J. (2018a): Out of the Frying Pan into the Fire? From Municipal Lords to the Global Assembly Lines - Roma's Experiences of Social (Im)mobility Through Migration From North Hungary. Intersections EEJSP 3., 4-28. https://doi.org/10.17356/ieejsp.v4i3.479

Durst J. (2018b): „Ez se élet, ez a kóborlás”. A helyi kiskirályoktól a globális futószalagig: észak-magyarországi roma transznacionális munkások mobilitási tapasztalatai. In: Váradi M.M. (szerk.): Migráció alulnézetból. MTA KRTK Regionális Kutatások Intézete, Argumentum, Budapest, 43-73.

Durst J. (2019): Transzmigránsok vagy vándormunkások? Az alacsony iskolázottságú észak-magyarországi szegények egzisztenciális mobilitása és a transznacionalitás korlátai. Regio, 3., 79-114. https://doi.org/10.17355/rkkpt.v27i3.275

Erőss Á. (2020): Akik maradtak: pillanatfelvétel az otthon maradt közösségekről a kárpátaljai szórványban. Regio, 1., 138-170. https://doi.org/10.17355/rkkpt.v28i1.301 
Faist, T. (2010): Transnationalization and Development. In: Glick Schiller, N., Faist, T. (eds.): Migration, Development and Transnationalization. A Critical Stance. Critical Interventions: A Forum for Social Analysis, Volume 12, Berghahn Books, New York, Oxford, 63-99.

Faist, T. (2013): The Mobility Turn: A New Paradigm for the Social Sciences? Ethnic and Racial Studies, 11., 1637-1646. http:/dx.doi.org/10.1080/01419870.2013.812229

Faist, T. (2016): Cross-Border Migration and Social Inequalities. Annual Review of Sociology, 1., 323-346. https://doi.org/10.1146/annurev-soc-081715-074302

Feischmidt M. (2008): Menedék és depó - szociográfiai esszé egy baranyai aprófaluról. In: Váradi M.M.(szerk.): Kistelepülések lépéskényszerben. Új Mandátum Kiadó, Budapest, 102-132.

Fejős Z., Szijártó Zs. (2002): Egy tér alakváltozásai: esettanulmányok a Káli-medencéról. Néprajzi Múzeum, Budapest (Tabula könyvek 4.)

Fischer, P. A., Holm, E., Malmberg, G., Straubhaar, T. (2000): Why do People Stay? Insider Advantages and Immobility, HWWA Discussion Paper 112, Hamburgisches Welt-Wirtschafts-Archi (HWWA)/ Hamburg Institute of International Economics, https://www.researchgate.net/publication/ 235110978_Why_do_People_Stay_Insider-Advantages_and_Immobility (Letöltés: 2019.11. 21.)

Geda F. (2012): A tengerben élnek krokodilok. Enaiatollah Akbar igaz története. Atheneum Kiadó Kft., Budapest

Glick Schiller, N., Salazar, N. B. (2013): Regimes of Mobility Across the Globe. Journal of Ethnic and Migration Studies, 2., 183-200. http://dx.doi.org/10.1080/1369183X.2013.723253

Hannam, K., Sheller, M., Urry, J. (2006): Editorial: Mobilities, Immobilities and Moorings. Mobilities, 1., 1-22. https://doi.org/10.1080/17450100500489189

Hanson, S. (2010): Gender and mobility: new approaches for informing sustainability. Gender, Place \& Culture, 1., 5-23. https:/doi.org/10.1080/09663690903498225

Haartsen, T., Stockdale, A. (2018): S/elective belonging: how rural newcomer families with children become stayers. Popul Space Place 24: e2137. https://doi.org!10.1002/psp.2137

Hjälm, A. (2014): The 'Stayers': Dinamics of Lifelong Sedentary Behaviour in an Urban Context, Popul. Space Place 20, 569-580., https://doi.org/10.1002/psp.1796

Horzsa G. (2018): A fejlesztési környezet szerepe a belső vándorlás alakulásában. Szakirodalmi áttekintés. socio.hu 3., 25-41. https:/doi.org/10.18030/SOCIO.HU.2018.3.25

Huszti É. (2019): A hazai pálya előnye. A társas kapcsolatok szerepe a falusi fiatalok immobilitásában. Metszetek, 3., 23-54. https://doi-org/10.18392/metsz/2019/3/2

Jónsson, G. (2011): Non-migrant, sedentary, immobile, or 'left behind'? Reflections on the absence of migration. Working Papers 39. International Migration Institute, Oxford https://ora.ox.ac.uk/objects/ uuid:ecaf96f8-caa0-4421-8ec6-107992e33c96 (Letöltés: 2020. február 26.)

Kaufmann, V. (2002): Re-thinking Mobility. Contemporary Sociology. Ashgate, Aldershot, idézi Canzler, Kaufmann, Kesselring 2008

Kaufmann, V., Widmer, E. D. (2006): Motility and Family Dynamics: Current Issues and Research Agendas. Zeitschrift für Familienforschung, Heft 1., 111-129. https://www.researchgate.net/publication/37446534_Motility_and_Family_Dynamics_Current_Issues_and_Research_Agendas (Letöltés: 2020.03.02.)

Kerülő J. (2019): Az immobilitást növelő és csökkentő települési jellemzők. Metszetek, 3., 184-232. https://doi.org/10.18392/metsz/2019/3/10

Koltai L. (szerk.) (2018): A közfoglalkoztatás hatása a helyi gazdaságra, helyi társadalomra. Belügyminisztérium, Hétfa Kutatóintézet Kft., Budapest https://kozfoglalkoztatas.kormany.hu/ download/f/fc/42000BM_k\%C3\%B6zfoglalkoztat\%C3\%A1s_Tanulm\%C3\%A1ny_201809 28-merged.pdf

Kordel, S., Weidinger, T. (2018): Editorial. Current Processes of Immigration to European Peripheries: Status Quo, Implications and Development Strategies. In: Kordel, S., Weidinger, T., Jelen, I. (eds.): Processes of Immigration in Rural Europe. The Status Quo, Implications and Development Strategies. Cambridge Scholars Publishing, xv-xxi.

Kovai, C. (2019): Permanent wage labour as a norm. Workfare policy and everyday experiences of precariousness in a small Hungarian former industrial town. socio.hu: Társadalomtudományi Szemle, Special Issue, 143-161. https://doi.org/10.18030/socio.hu.2019en.142 
Kovai C., Vigvári A. (2020): Befejezetlen proletarizáció? A vidéki munkaerő-tartaléksereg Magyarországon a 2008-as válságot követően. Tér és Társadalom, 3., 68-89. https://doi.org/10.17649/TET. 34.3.3284

Kovách I. (2012): A vidék az ezredfordulón: A jelenkori magyar vidéki társadalom szerkezeti és hatalmi változásai. Argumentum Kiadó, Budapest

Kovács É. (2008): „Ki vagyunk esve a külvilágból” - A lengyári kolónia. In: Váradi M.M.(szerk.): Kistelepülések lépéskényszerben. Új Mandátum Kiadó, Budapest, 133-159.

Krémer B. (2019): Miért ésszerű maradni, ha egyszer nem az? - Szempontok az „immobilitás-kutatás” feldolgozásához és elemzéséhez. Metszetek, 3., 233-249. https://doi.org/10.18392/metsz/2019/3/11

Lieszkovszky J. P. (2018): A közlekedési eredetű kirekesztettség által érintett társadalmi csoportok vizsgálata hátrányos helyzetű vidéki térségekben. In: Munkácsy A., Jászberényi M. (szerk.): Utazás a tudományban. Konferencia a 70 éves Pálfalvi József tiszteletére. Konferenciakötet. Budapesti Corvinus Egyetem, Budapest, 90-94. http://old.uni-corvinus.hu/fileadmin/user_upload/hu/tanszekek/ gazdalkodastudomanyi/i_mark/kk_tt/UaT2018_Palfalvijozsef70_koetet.pdf (Letöltés: 2020.03. 21.)

Lieszkovszky, J. P. (2018). Introduction to the theoretical analysis of social exclusion of public transport in rural areas. Deturope, 3., 214-227. http://www.deturope.eu/img/upload/content_97222251.pdf (Letöltés: 2020. 03. 21.)

Lutz, H. (2010): Gender in the migratory process. Journal of Ethnic and Migration Studies, 10.,1647-1663. https://doi.org/10.1080/1369183x.2010.489373

Mahler, S. J., Pessar, P. R. (2006):Gender matters: ethnographers bring gender from the periphery to the core of migration studies. International Migration Review, 1., 27-63. https://doi.org/10.1111/ j.1747-7379.2006.00002.x,

Mata-Codesal, D. (2015): Ways of Staying Put in Ecuador: Social and Embodied Experiences of Mobility-Immobility Interactions. Journal of Ethnic and Migration Studies, https://doi.org/ 10.1080/1369183X.2015.1053850

Mata-Codesal, D. (2018): Is it simpler to leave or to stay put? Desired immobility in a Mexican village. Popul Space Place 2018:24: e2127. https://doi.org/10.1002/psp.2127

Merriman, P., Revill, G., Cresswell, T., Lorimer, H., Matless, D., Rose, G., Wylie, J. (2008): Landscape, mobility, practice. Social \& Cultural Geography, 2., 191-212. https://doi.org/10.1080/146493607011856136

Merriman, P., Jones, R., Cresswell, T., Divall, C., Mom, G., Sheller, M., Urry, J. (2013): Mobility: Geographies, Histories, Sociologies. Transfers, 1., 147-165. https://doi. org/10.3167/TRANS.2013.030111

Molnár É. (2019): A család hatása a falusi fiatalok immobilitására. Metszetek, 3., 153-166. https:// doi.org/10.18392/metsz/2019/3/8

Nagy T. (2019): Itt lehet vagy kell maradni? Mobilitástörténetek. Metszetek, 3., 86-100. https:// doi.org/10.18392/metsz/2019/3/4

Németh K. (2016): Mobilitási utak egy mezőgazdasági nagyüzem dicsfényében és árnyékában. In: Kovács K. (szerk.): Földből élők. Polarizáció a magyar vidéken. Argumentum, 161-185.

Németh K. (2020): „Cseberből vederbe” - A mikromobilitás mintázatai egy marginalizált mikrotérben. Tér és Társadalom, 3., 90-113. https://doi.org/10.17649/TET.34.3.3279

Németh, K., Váradi, M. M. (2018): Development in the Context of Care Migration from Rural Hungary: An agency-based approach. Review of Sociology of the Hungarian Sociological Association, 4., 88-110.

Ní Laoire, C. (2001): A Matter of Life and Death? Men, Masculinities and Staying 'Behind' in Rural Ireland, Sociologia Ruralis, 2., 220-236. https://doi.org/10.1111/1467-9253.00179

Róin, Á. (2015): The multifaceted notion of home: Exploring the meaning of home among elderly people living in the Faroe Islands. Journal of Rural Studies, 39., 22-31. https://doi.org/10.1016/ j.jrurstud.2015.03.002

Rosenberg, E., Shannon, K. (2018): Im/mobility: Connecting Disciplines. An Editorial Introduction. Geography Research Forum, Volume 38., 1-15. https://www.academia.edu/38812712/Im_mobility_Connecting_Disciplines___An_Editorial_Introduction_Editorial?auto=download (Letöltés: 2020. 03.12.)

Salazar, N. B. (2017): Theorizing mobility through concepts and figures. Tempo Social, 2., 153-168. https://dori.org/10.11606/0103-2070.ts.2018.142112

Schewel, K. (2015): Understanding the Aspiration to Stay. A Case Study of Young Adults in Senegal. Working Paper 107, Working Papers, International Migration Institute (IMI), Oxford Department of 
International Development (QEH), University of Oxford. https:// www.imi.ox.ac.uk/pdfs/wp/wp107-15pdf (Letöltés: 2016. 03.21.)

Schewel, K. (2019): Understanding Immobility: Moving Beyond the Mobility Bias in Migration Studies. International Migration Review, 1-29. https://doi.org10.1177/0197918319831952

Sen, A. (2003): A fejlődés mint szabadság. Európa Könyvkiadó, Budapest

Sheller, M. (2013): Sociology After the Mobilities Turn from: The Routledge Handbook of Mobilities. Routledge https://www.routledgehandbooks.com/doi/10.4324/9781315857572.ch3 (Letöltés: 2019. 08. 22.)

Sheller, M., Urry, J. (2006): The new mobilities paradigm. Environmental and Planning A, 38., 207-226. https://doi.org/10.168/a37268

Silvey, R. (2004): Power, difference and mobility: feminist advances in migration studies. Progress in Human Geography, 4., 1-17. https://doi.org/10.1191/0309132504ph490oa

Stockdale, A., Haartsen, T. (2018): Editorial introduction: Putting rural stayers in the spotlight. Popul Space Place, 2018; 24: e2124. https://doi.org/10.1002/psp.2124

Szelényi, I. (2016): Pakistani Guest Workers in The United Arab Emirates. Demográfia 4., English Edition, 5-47. https://doi-org/ 10.21543/DEE.2016.1

Urry, J. (2000): Sociology beyond Societies. Mobilities for the twenty-first century. Routledge, London and New York

Urry, J. (2002): Mobility and Proximity. Sociology, 2., 255-274. https://doi.org/ 10.1177/0038038502 036002002

Van Houtum, H.,Van der Velde, M. (2004): The Power of Cross-Border Labour Market Immobility. Tijdschrift voor Economische en Sociale Geografie, 1., 100-117.

Van Naerssen, T.,Van der Velde, M. (2015): Prologue: The Thresholds to Mobility Disentangled. In: Van der Velde, M., Van Naerssen, T. (eds.): Mobility and Migration Choices. Ashgate Border Regions Series, 3-14.

Váradi M.M.(szerk.) (2008): Kistelepülések lépéskényszerben. Új Mandátum Kiadó, Budapest

Váradi M. M. (2013): Megélhetés és támogató kapcsolatok - az aprófalusi szegénység arcai. In: Kovács K., Váradi M. M. (szerk.): Hátrányban Vidéken Argumentum Kiadó, 106-131.

Váradi M. M. (2016): Mennek, maradnak, visszajönnek. In: Sikos T. T., Tiner T. (szerk.): Tájak, régiók, települések térben és idóben. Tanulmánykötet Beluszky Pál 80. születésnapjára. Dialóg Campus Kiadó, Budapest, 461-472.

Váradi M. M. (2018): Elméleti kaleidoszkóp - a migrációs tapasztalatok értelmezési lehetőségei. In: Váradi M. M. (szerk.): Migráció alulnézetból. MTA KRTK Regionális Kutatások Intézete, Argumentum, 13-42.

Váradi M. M., Durst J., Fehér K., Németh K.,Virág T. (2017): Kényszerű mobilitás: migrációs utak hátrányos helyzetű vidéki terekben. socio.hu, 3., 25-46. https://doi.org/10.18030/SOCIO.HU. 2017.3.25

Vidra, Zs. (2013a): Introduction. Theorizing Roma Migration to Canada. In Vidra, Zs. (ed.): Roma Migration to and from Canada. The Czech, Hungarian and Slovak Case. Center for Policy Studies Central European University, 5-20.

Vidra Zs. (2013b): A szakképzetlen bérmunka szerepe falusi romák megélhetési stratégiáiban. In: Kovács K., Váradi M. M. (szerk.): Hátrányban Vidéken Argumentum Kiadó, 57-74.

Vigvári, A. (2016): 'Rural poverty' in urban spaces of Budapest: Research proposal for examining spatial inequality in contemporary Hungary. socio.hu, 4., 47-61.https://doi.org/10.18030/SOCIO.HU2016EN.47

Virág T. (2007): Migrációs folyamatok az aprófalvakban. In: Kovács É. (szerk.): Közösségtanulmány. Módszertani jegyzet. Néprajzi Múzeum, PTE-BTK Kommunikáció-és Médiatudományi Tanszék, 134-146.

Virág T. (2010): Kirekesztve. Falusi gettók az ország peremén. Akadémia Kiadó, Budapest

Virág, T., Váradi, M. M. (2017): Spatial Exclusion and Boundary-Making in Different Roma Neighbourhoods in Hungarian Rural Small Towns. Tijdschrift Voor Economische En Sociale Geografie/ Journal of Economic and Social Geography. 4., 485-498. https://doi.org/10.1111/tesg.12300 